University of Nebraska - Lincoln

DigitalCommons@University of Nebraska - Lincoln

USGS Staff - Published Research

US Geological Survey

2011

\title{
Soil carbon distribution in Alaska in relation to soil-forming factors
}

Kristofer D. Johnson

University of Alaska, kristoferdjohnson@fs.fed.us

Jennifer Harden

U.S. Geological Survey

A. David McGuire

University of Alaska

Norman B. Bliss

ARTS, bliss@usgs.gov

James G. Bockheim

University of Wisconsin

See next page for additional authors

Follow this and additional works at: https://digitalcommons.unl.edu/usgsstaffpub

Part of the Earth Sciences Commons

Johnson, Kristofer D.; Harden, Jennifer; McGuire, A. David; Bliss, Norman B.; Bockheim, James G.; Clark, Mark; Nettleton-Hollingsworth, Teresa; Jorgenson, M. Torre; Kane, Evan S.; Mack, Michelle; O'Donnell, Jonathan; Ping, Chien-Lu; Schuur, Edward A.G.; Turetsky, Merritt R.; and Valentine, David W., "Soil carbon distribution in Alaska in relation to soil-forming factors" (2011). USGS Staff -- Published Research. 495.

https://digitalcommons.unl.edu/usgsstaffpub/495

This Article is brought to you for free and open access by the US Geological Survey at DigitalCommons@University of Nebraska - Lincoln. It has been accepted for inclusion in USGS Staff -- Published Research by an authorized administrator of DigitalCommons@University of Nebraska - Lincoln. 


\section{Authors}

Kristofer D. Johnson, Jennifer Harden, A. David McGuire, Norman B. Bliss, James G. Bockheim, Mark Clark, Teresa Nettleton-Hollingsworth, M. Torre Jorgenson, Evan S. Kane, Michelle Mack, Jonathan O'Donnell, Chien-Lu Ping, Edward A.G. Schuur, Merritt R. Turetsky, and David W. Valentine 


\title{
Soil carbon distribution in Alaska in relation to soil-forming factors
}

\author{
Kristofer D. Johnson ${ }^{a, *}$, Jennifer Harden ${ }^{b}$, A. David McGuire ${ }^{\text {a }}$, Norman B. Bliss ${ }^{\text {c }}$, James G. Bockheim ${ }^{\text {d }}$, \\ Mark Clark ${ }^{\mathrm{e}}$, Teresa Nettleton-Hollingsworth ${ }^{\mathrm{f}}$, M. Torre Jorgenson ${ }^{\mathrm{g}}$, Evan S. Kane ${ }^{\mathrm{h}}$, Michelle Mack ${ }^{\mathrm{i}}$, \\ Jonathan O'Donnell ${ }^{\mathrm{j}}$, Chien-Lu Ping ${ }^{\mathrm{k}}$, Edward A.G. Schuur ${ }^{\mathrm{i}}$, Merritt R. Turetsky ${ }^{1}$, David W. Valentine ${ }^{\mathrm{m}}$ \\ a U.S. Geological Survey, Alaska Cooperative Fish and Wildife Research Unit, University of Alaska, Fairbanks, AK 99775, USA \\ b U.S. Geological Survey, Menlo Park, CA 94025, USA \\ c ARTS, U.S. Geological Survey, Sioux Falls, SD 57198, USA \\ d Department of Soil Science, University of Wisconsin, Madison, WI 53706, USA \\ e USDA, Natural Resources Conservation Service, Palmer, AK 99645, USA \\ ${ }^{\mathrm{f}}$ Boreal Ecology Cooperative Research Unit, USDA Forest Service Pacific Northwest Research Station, Fairbanks, AK 99775, USA \\ ${ }^{g}$ Alaska Ecoscience, 2332 Cordes Way, Fairbanks, AK 99709, USA \\ h School of Forest Resources and Environmental Science, Michigan Technological University, Houghton, MI 49931, USA \\ i Department of Botany, University of Florida, Gainesville, FL 32611, USA \\ j Department of Biology and Wildlife, University of Alaska Fairbanks, Fairbanks, AK 99775, USA \\ ${ }^{\mathrm{k}}$ Agricultural and Forestry Experiment Station, University of Alaska, Fairbanks, AK 99775, USA \\ ${ }^{1}$ Deparment of Integrative Biology, University of Guelph, Guelph, ON, Canada N1G 1G2 \\ m Department of Forest Science, University of Alaska Fairbanks, Fairbanks, AK 99775, USA
}

\section{A R T I C L E I N F O}

\section{Article history:}

Received 9 November 2010

Received in revised form 24 September 2011

Accepted 2 October 2011

Available online 2 November 2011

\section{Keywords:}

Soil carbon

Soil forming factors

Arctic

Boreal

Permafrost

Alaska

\begin{abstract}
A B S T R A C T
The direction and magnitude of soil organic carbon (SOC) changes in response to climate change remain unclear and depend on the spatial distribution of SOC across landscapes. Uncertainties regarding the fate of SOC are greater in high-latitude systems where data are sparse and the soils are affected by sub-zero temperatures. To address these issues in Alaska, a first-order assessment of data gaps and spatial distributions of SOC was conducted from a recently compiled soil carbon database. Temperature and landform type were the dominant controls on SOC distribution for selected ecoregions. Mean SOC pools (to a depth of 1-m) varied by three, seven and ten-fold across ecoregion, landform, and ecosystem types, respectively. Climate interactions with landform type and SOC were greatest in the uplands. For upland SOC there was a six-fold non-linear increase in SOC with latitude (i.e., temperature) where SOC was lowest in the Intermontane Boreal compared to the Arctic Tundra and Coastal Rainforest. Additionally, in upland systems mineral SOC pools decreased as climate became more continental, suggesting that the lower productivity, higher decomposition rates and fire activity, common in continental climates, interacted to reduce mineral SOC. For lowland systems, in contrast, these interactions and their impacts on SOC were muted or absent making SOC in these environments more comparable across latitudes. Thus, the magnitudes of SOC change across temperature gradients were non-uniform and depended on landform type. Additional factors that appeared to be related to SOC distribution within ecoregions included stand age, aspect, and permafrost presence or absence in black spruce stands. Overall, these results indicate the influence of major interactions between temperature-controlled decomposition and topography on SOC in high-latitude systems. However, there remains a need for more SOC data from wetlands and boreal-region permafrost soils, especially at depths $>1 \mathrm{~m}$ in order to fully understand the effects of climate on soil carbon in Alaska.
\end{abstract}

Published by Elsevier B.V.

\section{Introduction}

As much as half of the world's soil organic carbon (SOC) is stored in northern soils (Tarnocai et al., 2009) and projected increases in air temperature are expected to occur more rapidly at high latitudes (IPCC, 2007). SOC stored in high-latitude ecosystems is a potentially

\footnotetext{
* Corresponding author at: 11 Campus Blvd. Ste 200, Newtown Square, PA 19073, USA. Tel.: +1 907474 5665; fax: +1 9074747872 .

E-mail addresses: kristoferdjohnson@fs.fed.us, kristof2@sas.upenn.edu (K.D. Johnson).
}

vulnerable component of the global carbon cycle (e.g. McGuire et al., 2009; Ping et al., 2008b; Schuur et al., 2008; Smith and Fang, 2010; Zimov et al., 2006). In high-latitude regions, high stocks of carbon are held in frozen mineral soils and both frozen and unfrozen peatland soils, all of which are vulnerable to soil warming (Dutta et al., 2006; Ping et al., 1997). Additionally, approximately a quarter of Earth's vegetated land cover is in the arctic and boreal regions (McGuire et al., 2009) so that even soils with low SOC contents can store large amounts of SOC on an areal basis. Despite increasing availability of spatial data products and advances in process-based modeling studies, there remain challenges in basic quantification of soil carbon in relation to soil forming 
factors (Jenny, 1941) in high-latitude biomes. This is partly due to a relative scarcity of SOC observations in boreal and arctic regions, which must be extrapolated over large and topographically complex areas. Furthermore, much less emphasis has been placed on SOC below organic horizons, revealing a vertical data gap (Ping et al., 2010). Thus, obtaining baseline soil carbon data at high latitudes is a challenge for our ability to understand and model terrestrial carbon feedbacks to the atmosphere.

In Alaska, not only are soil properties strongly linked to vegetation, topography, and parent material (Ping et al., 2004, 2005; Swanson, 1996; Turetsky et al., 2005), but climate also plays a major role in SOC content across Polar, Boreal, and Maritime ecoregions (Post et al., 1982). For example, data from nine profiles suggest that tundra soils hold the highest non-wetland soil carbon contents (314 to $599 \mathrm{MgC} \mathrm{ha}^{-1}$ ) followed by southern coastal forests (240 to $437 \mathrm{MgC} \mathrm{ha}^{-1}$ ) and interior boreal forests (169 to $787 \mathrm{MgC} \mathrm{ha}^{-1}$ ) (Ping et al., 1997). Differences in SOC between Polar and Boreal ecoregions is due to cryoturbation and permafrost occurrence which are associated with colder climates (see also Bockheim, 2007; Bockheim and Hinkel, 2007; Ping et al., 2008a). In contrast, higher SOC in southeast Alaska compared to the interior may be related to high precipitation and organic inputs (Ping et al., 2002). Therefore, the boundaries between Polar, Boreal and Maritime ecoregions represent interesting gradients in temperature and precipitation that may be affected by climate change, with consequences for soil carbon pools (Harden et al., 2008; Steltzer, 2004; Stottlemyer et al., 2001; Wilmking et al., 2006). Further, since potentially one-third of the SOC in the U.S. is stored in Alaska (Bliss and Maursetter, 2010; Guo et al., 2006), SOC dynamics in this state alone directly impact national and continental scale cycling of terrestrial carbon.

Our assessment of the magnitude and distribution of SOC in Alaska involved several objectives. First, we compiled soil carbon data from a variety of academic and government sources to a 1-m depth to provide the most comprehensive, standardized database of SOC in Alaska to date. Second, we partitioned the variability in SOC across Alaska at the ecoregion, landscape, and ecosystem levels as a means of assessing the distribution of SOC across the state. Finally, as a first-order (i.e., basic) assessment of SOC variability in Alaska, we evaluated the role of various soil-forming factors, including climate, in controlling SOC distributions using simple univariate statistics and multiple linear regression. Although the study is focused in Alas$\mathrm{ka}$, it may be viewed as a case study of pedogenesis and SOC content for similar high-latitude soil environments.

\section{Methods}

\subsection{Soil carbon database}

This study uses a variety of soil profile datasets with geocoordinates (Fig. 1) from both academic and government sources (including the State Soil Geographic Database, STATSGO) that differ somewhat in their sampling and lab analysis protocols. Three datasets of total profile SOC, but for different depths, were derived from the database for the purposes of this study: 1) 1-m SOC $\left(\mathrm{Mg} \mathrm{ha}^{-1}\right)$, which included the summed SOC of all horizons from the top of the organic layer to the depth of bedrock or $100 \mathrm{~cm}$ depth $(\mathrm{n}=554), 2) 50 \mathrm{~cm}$ mineral SOC, calculated for the $0-50 \mathrm{~cm}$ mineral depth below the organic-mineral interface $(n=603)$, and 3$)$ organic layer soil carbon $(n=592)$. References to SOC content are for the 1-m SOC pool unless otherwise noted. Most profiles were sampled by horizon type while a smaller number where sampled at fixed depths.

Soil carbon content in most soil profiles were calculated by simply adding together soil carbon content of individual layers. However, bulk density measurements were missing from $40 \%$ of the sampled layers in the combined dataset (15\% organic and $25 \%$ mineral). To fill in gaps, predictive models were developed that estimate bulk density from carbon concentration $(\% C)$ in mineral soils and carbon content $\left(\mathrm{gC} \mathrm{cm}^{-2}\right)$ in organic layers (Appendix 1). Equations were sought that would apply to specific horizons and, in some cases, for specific ecoregions. An uncertainty analysis was also carried out to assess if propagated model errors would affect ANOVA test results (below).

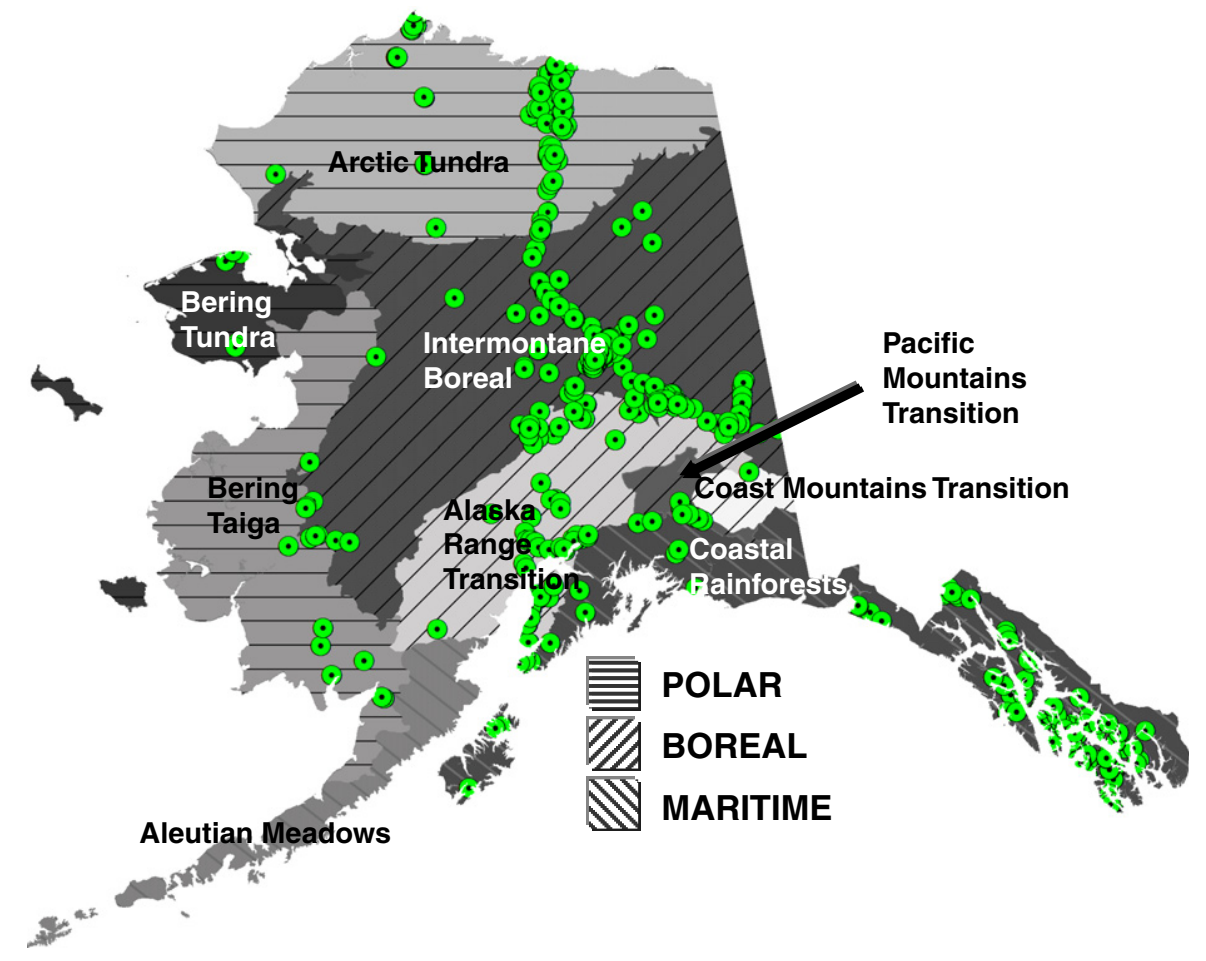

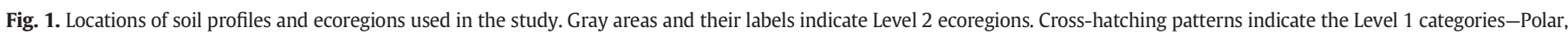
Boreal, and Maritime. 
After the adjustments and predictions from Appendix Table 1 were made, soil carbon content (SOC) $\left(\mathrm{Mg} \mathrm{ha}^{-1}\right)$ was calculated by the equation:

SOC $=100 *\left(\right.$ thickness $*$ carbon $*$ bulk $k_{d}$ ensity $)$

where thickness is of the soil layer $(\mathrm{cm})$, carbon is the concentration of total carbon measured by dry combustion (\%) (or adjusted from wet combustion, see Appendix 1), and bulk_density is for the $<2 \mathrm{~mm}$ fraction $\left(\mathrm{g} \mathrm{cm}^{-3}\right)$. Where data for the $>2 \mathrm{~mm}$ fraction was available, the equation was adjusted to calculate carbon content. For about $25 \%$ of the profiles it was uncertain whether coarse fragments were present in the profile. A correction factor of 0.01 , based on available empirical data, was applied to the SOC content of some profiles were this information was not available but where it was likely that rock content was high. However, we recognize that this figure may be low for some till substrates (see sensitivity analysis below).

Calculating SOC using the above equation cannot always be applied to highly cryoturbated soils in the Arctic Tundra region. Therefore, for cryoturbated profiles only, published values for the total $1-\mathrm{m}$ pool were directly added to the database. A simple ratio was applied to the "mineral" part of the soil (the $1-\mathrm{m}$ SOC minus the surface organic layer) to approximate organic carbon content of the 0 to $50 \mathrm{~cm}$ mineral soil carbon content for cryoturbated profiles only (50 $\mathrm{cmSOC}, \mathrm{Mg} \mathrm{ha}^{-1}$ ):

$50 \mathrm{cmSOC}=(1 \mathrm{mSOC}-$ OlayerSOC $) * \frac{50 \mathrm{~cm}}{(100 \mathrm{~cm}-\text { OlayerDepth })}$,

where $1 \mathrm{mSOC}$ is the total soil carbon content (including the organic layer) to a 1-m depth ( $\left.\mathrm{Mg} \mathrm{ha}^{-1}\right)$, OlayerSOC is the surface organic layer soil carbon content $\left(\mathrm{Mg} \mathrm{ha}^{-1}\right)$, and OlayerDepth is the depth of the organic layer $(\mathrm{cm}, \leq 100 \mathrm{~cm})$. This approach assumes an equal distribution of SOC in cryoturbated soils with depth (c.f. Michaelson et al., 1996; Bockheim and Hinkel, 2007). Surface organic layer carbon in Arctic regions that was not subsumed into the mineral matrix was calculated in the same manner as non-cryoturbated profiles.

\subsection{Ecoregions in Alaska}

The study includes data from the entire state of Alaska, divided by various levels of ecoregions as defined by Nowacki et al. (2001) (Fig. 1). Thirty-two ecoregions ("Commoners") were delineated along climate and vegetation gradients. These are grouped into three Level 1 regions, "Polar", "Boreal", and "Maritime", and nine Level 2 regions. Much of the current study is focused on four Level 2 ecoregions, "Intermontane Boreal", "Arctic Tundra”, "Alaska Range Transition", and "Coastal Rainforests", because of the richness in observations in these areas. The distribution and areal extent of Level 2 ecoregions are similar to the Major Land Resource Areas (MLRA's) used by the Natural Resources Conservation Service (USDA, 2006). Level 1 and Level 2 regions were used in combination with land cover and landform classes for exploring data gaps, and for discussing broad scale changes in SOC across the state. Geography, climate regimes, geology, vegetation cover and fire activity distinguish ecoregions and their soils. The Intermontane Boreal, unlike other parts of Alaska, was never glaciated but is well marked by braided rivers from glacial runoff from adjacent regions (Ping et al., 2006).

\subsection{Proxies for soil forming factors}

Site attributes such as vegetation cover, parent material, soil drainage, slope and aspect were inconsistently recorded in the datasets. Therefore, for the purposes of this study, soil forming factors were represented by mostly GIS information which was overlaid and extracted to point observations. The level of accuracy of this approach depends on the type of information and scale of the data layer from which it was extracted (see below). All data extractions were performed in the Alaska Albers Equal Area Conic projection with North American Datum 1983 using ArcInfo software (Environmental Systems Research Institute, 2010).

\subsubsection{Landcover}

Landcover data were obtained from the $30 \mathrm{~m}$ National Landcover Database (2001 NLCD; Homer et al., 2004) for the year 2001. The NLCD has been used previously in the study of state factor effects on soil carbon distribution in the conterminous U.S. (Guo et al., 2006). Most of the soil-bearing areas in Alaska are defined by categories of "evergreen forest", "deciduous forest", "mixed forest", "shrub/scrub", "dwarf shrub", "sedge", "woody wetland", and "emergent herbaceous wetland". For some analyses, the three forest classes and two shrub classes were each combined into two general classes-"forest" and "shrub". For Intermontane Boreal analyses, evergreen forest was separated into "black spruce" and "white spruce" based on field notes. The 2001 NLCD vegetation cover is highly correlated with topography. For example, deciduous forests will occur mostly on south and west facing aspects in upland areas and in locally well-drained lowland locations. Shrubs occur under a variety of conditions including cold upland slopes, lowland black spruce woodlands, and recently disturbed areas (i.e. floodplains, fire scars) (Edwards and Armbruster, 1989; Viereck et al., 1983).

The NLCD land cover classes extracted to observation points were generally consistent with field observations, when such observations were available. Much of the initial misclassification was due to discrepancies between the sampling date and the date of the 2001 NLCD (e.g., soils sampled on forested lands that were later commercially developed). Profiles were sampled mostly between the years 1980 and 2010 and less than $10 \%$ of them were sampled as early as the 1950's. Field notes were available for only $77 \%$ of the observations. From the observations with field notes, we were able to determine that $56 \%$ of them were identified correctly by the NLCD map. If we apply this ratio to the remaining observations with no field notes, then we predict that $90 \%$ of the observations were likely correctly identified. It is important to note that land cover in this study was not used as a predictor variable, but rather to stratify data.

\subsubsection{Proxy for parent material and topography}

Landform type for each of the observations was assigned and defined from parent material texture, digital elevation model (DEM), and land cover layers. A $60 \mathrm{~m}$ USGS DEM of Alaska was re-sampled to $1 \mathrm{~km}$ for efficiency in creating landform classes. Landforms were defined in such a way as to represent broad categories of soil drainage conditions that are common in Alaska. Although this approximation of soil drainage may be crude at the point scale, it represents larger scale drainage in the surrounding landscape. Further, this approach relies on raster DEM-derived attributes of topography (e.g. slope) instead of STATSGO soil map units which are still only coarsely mapped in Alaska (Bliss and Maursetter, 2010).

The parent material, DEM and land cover layers were combined to develop discreet landform units using the following steps. First, parent material texture-"Rocky or Variable", "Sandy" and "Silty"-mapped by Jorgenson et al. (2008) was extracted to each of the observations. In the Intermontane Boreal, areas mapped as Sandy and Silty were mostly river floodplains, or areas adjacent to floodplains. In contrast, Sandy and Silty sources in the Arctic Tundra were mostly marine deposits. Till made up most of the Rocky or Variable textures that occurred nearly everywhere else in the state. Second, slope and topographic position index (TPI) from the $1 \mathrm{~km}$ DEM (USGS) were combined to delineate upland and lowland areas. Topographic position index is essentially a measure of hillslope position where positive values represent topographic high points (e.g. ridges) and negative values are topographic low points (e.g. valleys) (Weiss, 2001). It is calculated as the difference of a cell's elevation and the mean elevation of a 
ring of cells around it (using the Benthic Terrain Modeler tool for ArcMap; Wright et al., 2005). Slope (\%) further distinguishes landform type where gently sloped areas and topographic low points are considered lowlands while moderately and steeply sloped areas are uplands. Formally, "Upland" areas were defined as: 1) TPI $\geq 4$ and slope $\geq 0$ and 2) TPI $<4$ and slope $\geq 10$. "Lowland" areas were defined as $\mathrm{TPI}<4$ and $0<$ slope $<10$. Third, Upland and Lowland classes were combined with the Rocky, Sandy and Silty classes. This resulted in five combinations-"Rocky or Variable Upland", "Rocky or Variable Lowland", "Sandy Lowland", "Silty Upland", and "Silty Lowland" ("Sandy Upland" is a rare combination in Alaska and was ignored in this study). Rocky or Variable Uplands and Rocky or Variable Lowlands together comprise $62 \%$ of the state and can be thought of as general categories where the "Sandy" and "Silty" modifiers do not apply. For convenience, we refer to Rocky or Variable landforms as simply "Uplands" and "Lowlands". Lastly, "Wetlands" were distinguished from other lowland areas by superposing "emergent herbaceous wetland" and "woody wetland" NLCD land cover classifications on each observation, regardless of its previous classification under the first two steps.

\subsubsection{Proxy for climate}

Climate information was obtained from the Parameter-Elevation Regression on Independent Slopes Model (PRISM), a product of Spatial Climate Analysis Service at Oregon State University (Daly et al., 2001). PRISM algorithms account for important spatial differences in Alaskan climate such as winter inversion, coastal proximity and elevation. The spatial resolution of monthly air temperature and precipitation are $2 \mathrm{~km}$ and averaged from 1961 to 1990. In addition to mean annual temperature and precipitation (MAT, MAP), mean summer (June, July, August; MST, MSP) and winter (December, January, February; MWT, MWP) temperature and precipitation were also derived and extracted to each soil carbon observation. Growing season length (GSL) was derived from the number of days between the date of thaw and date of freezing. Additionally, MST-MWT was derived and used as an index of continentality (Kauppi and Posch, 1985) and indicator of shifting seasonal climatic regimes and fire activity. Surface air temperatures can be problematic proxies for soil temperature which largely control productivity and decomposition because of the influence of organic layer and snow depth and other topographic variables (e.g. Jorgenson et al., 2010; Yi et al., 2009). However, for broad regional comparisons, these variables may correlate with soil temperature and processes which govern SOC storage (e.g., Bond-Lamberty and Thomson, 2010; Guo et al., 2006).

\subsubsection{Other climatic, biotic, and topographic proxies}

Folded aspect was calculated to reflect heat load differences where southwest facing slopes $\left(225^{\circ}\right.$ clockwise from North) are the highest and northeast facing slopes $\left(45^{\circ}\right)$ are the lowest (McCune and Dylan, 2002):

folded aspect $=|180-|$ aspect -225|| .

Profiles that had permafrost in the top 1-m of soil and those without permafrost were labeled accordingly for means comparisons. Most of the profiles in the dataset $(81 \%)$ did not have permafrost in the top 1 -m of soil. Active layer depth was not consistently measured across all the observations. In the few cases that it was noted it was calculated as the depth from the top of the surface organic layer to the top of the perennially frozen layer (denoted by "f"). Stand age was also noted inconsistently. However fire perimeters and the year of fire events have been mapped for Alaska since 1943 (BLM, 2008) and were used to approximate stand age for observations where this information was missing. Stand ages were then grouped as "young forests" ( $<65$ years) or "mature forest" ( $>65$ years) for means comparisons and controlling for stand age effects in the presence of other predictors.

\subsection{Data analysis}

Comparisons of SOC were made at various scales within Alaska (i.e. levels of ecoregion, landform, and ecosystem partitioning) in addition to global SOC means. Differences in SOC content were assessed in a way that mimicked experimental control of temperature and landform. After individual profiles were assigned to specific ecoregions and landforms their SOC contents were assessed with one-way analysis of variance (ANOVA) tests. In each comparison, the data were log transformed to correct for data skewness and unequal variances were tested with the Levene test. When data distribution followed the assumptions of normality and approximately equal variances, the Tukey-Kramer HSD test was used at $P=0.05$. If variances were found to be unequal, a Welch's ANOVA test was applied allowing for unequal standard deviations. If variances were unequal and the sample population not normally distributed, then the Wilcoxon rank-sum test was applied. In all cases where post-hoc analysis was required, the appropriate Bonferroni statistic was used to determine statistical significance.

To control for landform, ecoregion was treated as the fixed effect for each landform. Similarly, to control for ecoregion, landform was treated as the fixed effect within a specific ecoregion. The same approach was used to compare SOC between vegetation types within the same landform and ecoregion. In addition to comparing SOC between Level 2 ecoregions for specific landforms, SOC was also compared without consideration of landform, i.e. a lumped ecosystem average. Partitioning profiles sometimes resulted in small groups, therefore, a cutoff of $<5$ profiles per group was used to determine if the group would be included in the ANOVA tests. To assess multiple effects on SOC, multiple linear regression was used to relate both climatic variables and organic layer depth to SOC content within Alaskan forests. All possible models with a maximum of two or three terms were assessed to find significant, parsimonious models of SOC distribution. Several tests were used to select the best fit models of SOC in Alaskan forests: 1 ) adjusted $R^{2}, 2$ ) root mean squared error (RMSE), and 3) corrected Akaike's Information Criterion (AICC). All statistical analyses were carried out with JMP software (SAS, version 8.0).

The model and overall approach used in this study to calculate individual profile SOC is somewhat complex and there is a possibility that model error may affect our comparisons of means across landforms and ecoregions (Appendix 1). Therefore, to address this, we applied a Monte Carlo method of propagating errors (Yanai et al., 2010) and observed what effect this had on the ANOVA tests applied for comparing mean SOC in the 1-m pool across ecoregions for specific landforms. For each iteration, we randomly applied the standard errors from the models of $\% C_{\text {tot }}$ and $T h$ (Appendix Table 1 ) simultaneously to each profile that required gap-filling. Then, new group comparisons were performed for all of the profiles in the same way as outlined above. After these steps were repeated 100 times, we found that the range of p-values never changed the results of the comparisons.

We performed additional analyses to understand the effect of certain deficiencies in the dataset in several ways. First, 178 profiles from Table 2 needed no gap-filling and could therefore be used as validation. When measured 1-m SOC was compared to predicted SOC, the slope was not significantly different than $1(\mathrm{P}=0.05)$, although 8 of the profiles had predicted SOC that was 50 to $80 \%$ different from the measured value. Several of these outliers were peatland soils and so it is possible that the gap-filling approach may underestimate SOC at these locations. Second, to assess the effect of adjusting $\% C_{\text {org }}$ on mean $1-\mathrm{m} \mathrm{SOC}$, we compared three approaches of calculating mean 1-m SOC from 29 profiles where $\% C_{\text {org }}$ and $\% C_{\text {tot }}$ overlapped: 1 ) using $\% C_{\text {tot }}$ only, 2) using $\% C_{o r g}$ only, and 3 ) using $\% C_{\text {adj }}$ only. All of the approaches yielded SOC estimates that were $<1 \%$ different from each other. Third, about $12 \%$ of the layers were known to have $\mathrm{pH} \geq 7.5$ (30\% of the layers had no $\mathrm{pH}$ data), but few layers were analyzed for carbonates. For profiles that had $\mathrm{pH}$ measurements $(\mathrm{n}=39)$, when calculations of profile SOC included carbonates the mean SOC was $1.3 \%$ lower than when the 
carbonates were not included. Therefore, a few profiles with high $\mathrm{pH}$ were likely underestimated by this amount. Lastly, recall that for about $25 \%$ of the profiles it was uncertain whether coarse fragments were present. Mean SOC calculated without coarse fragments was 4.4 and 3.2\% higher than mean SOC calculated with coarse fragments in the Silty Lowlands and Sandy Lowlands, respectively. The same calculations showed that Uplands and Lowlands were 1.4 and 1.0\%, higher, respectively, when coarse fragments were omitted. Therefore, for this subset of data where coarse fragments were missing, soils with sandy or silty parent materials could be somewhat overestimated even after our correction was applied. Overall, these analyses support that errors resulting from our approach in calculating SOC means are probably small for the purposes of comparing group means, although individual profiles may not be well predicted in some cases.

\section{Results}

\subsection{Representativeness of dataset relative to Alaska landscapes}

Data were richest in four of the five largest Level 2 regions in Alaska, the Intermontane Boreal, Coastal Rainforests, Arctic Tundra, and Alaska Range Transition, and profile data were generally proportional to areal coverage of each ecoregion (Fig. 2a, b). The exception was the third largest ecoregion, the Bering Taiga, which was poorly sampled. Most of this region is covered with shrubby vegetation (65\%) with lesser coverage from forests (14\%) and wetlands (14\%). Other poorly sampled Level 2 regions included the Bering Tundra and Aleutian Meadows which together make up $9 \%$ of Alaska.

Observations of 1-m SOC were generally well distributed across climate gradients for specific landform types, but there were several exceptions (Fig. 3). There were no observations in Silty landform types of the Brooks Foothills where the mean MAT is $-12{ }^{\circ} \mathrm{C}$ and MAP is $230 \mathrm{~mm}$. Additionally, while Silty Lowland observations were sampled regularly across the gradient from -7 to $-1{ }^{\circ} \mathrm{C}$, Silty Uplands had only two observations throughout the gradient. The undersampled Silty landforms in northern and central Alaska were predominantly loess deposits, especially in the lower Brooks Foothills, Kuskokwim Mountains and Yukon River Lowlands. Further, although there was notably good coverage of SOC observations for emergent wetlands near Barrow, AK $\left(-12.5^{\circ} \mathrm{C}\right.$ MAT, $180 \mathrm{~mm}$ MAP), observations were generally missing for the wider and more common climate gradient for wetlands found in the Arctic Tundra $\left(-12.5\right.$ to $-10{ }^{\circ} \mathrm{C}$ MAT, 180 to $400 \mathrm{~mm}$ MAP).

Combining data by Level 1 regions, land cover, and landform data resulted in 33 unique combinations that described $90 \%$ of Alaska's landscape (Fig. 4a,b). However, soil profile observations were not distributed evenly across the classes. For example, approximately $43 \%$ of Alaska is covered by shrubs with rocky parent material, yet only $9.5 \%$ of the observations fall in this category. Although there were 25 emergent wetland observations to a depth of $1-\mathrm{m}$ or more in the Polar regions, there were only 6 for the entire Boreal region. Other relatively sparsely sampled combinations ( $<5$ observations) that made up at least $3 \%$ of Alaska's landscape were the Boreal Lowland Shrubs and Polar Silty Lowland Shrubs. For the Maritime region, poorly sampled combinations included only the Lowland Shrubs. In contrast, some environments were sampled more densely, including the Polar Sedges (both upland and lowland), Maritime Evergreen Forests (both upland and lowland), Boreal Sandy Lowland Evergreen Forests, and Boreal Deciduous Forests (both upland and lowland).

It was unclear how well soil carbon contained in permafrost to a 1-m depth was represented by the dataset, especially in Boreal regions. According to the National Cooperative Soil Survey (NCSS) horizon designation convention (used for $92 \%$ of the dataset), permafrost is indicated by an "f" (i.e. "frozen") in the soil layer sampled (Schoeneberger et al., 2002). In the Arctic Tundra 75\% of the observations documented permafrost within the top 1-m of soil. In the Intermontane Boreal, however, only $18 \%$ were noted as having permafrost. We note that some profiles were not sampled to a 1-m depth (and therefore not included in our analysis) possibly due to permafrost inhibiting deeper sampling. Therefore it is possible that the proportion of profiles containing permafrost in our dataset is somewhat biased and may be higher. Moreover, we also note that the current dataset does not include permafrost or carbon deeper than the 1-m cutoff as these samplings were rare.

\subsection{Distribution of SOC by ecoregion, landform, and ecosystem for selected ecoregions}

\subsubsection{Partitioning SOC by ecoregion}

Within the most data-rich Level 2 ecoregions, mean 1-m SOC varied significantly $(\mathrm{P}<0.05)$, showing a three-fold difference from $140 \mathrm{Mg} \mathrm{ha}^{-1}$ in the Intermontane Boreal to 440 in Arctic Tundra (Fig. 2c). High SOC content was also observed in the Alaska Range Transition $\left(260 \mathrm{Mg} \mathrm{ha}^{-1}\right)$ and Coastal Rainforests ( $250 \mathrm{Mg} \mathrm{ha}^{-1}$ ), but these were still 1.7 and 1.8 times lower than the Arctic Tundra. Although sparsely sampled, the Bering Taiga and Bering Tundra regions had somewhat lower mean 1-m SOC (not significant P > 0.05) than the Arctic Tundra. Likewise, the Pacific Mountains Transition region (i.e. the Copper River Basin) was very similar in SOC levels to the Intermontane Boreal.

\subsubsection{Partitioning SOC by landform}

Partitioning the variability of $1-\mathrm{m}$ SOC by landform (the combination of topographic and parent material characteristics) resulted in an almost seven-fold difference among means $(\mathrm{P}<0.0001)$ (Table 1$)$. The

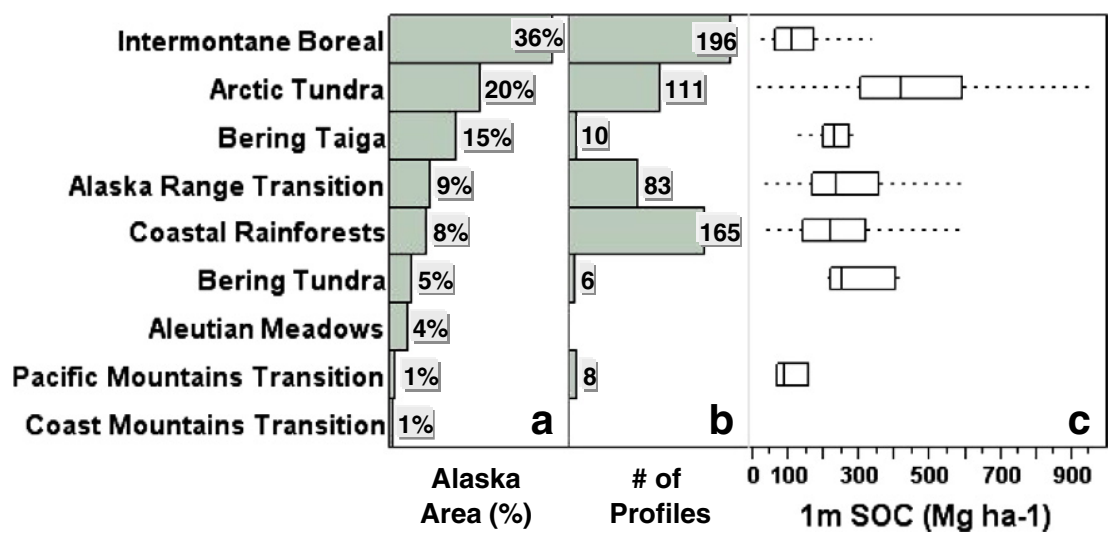

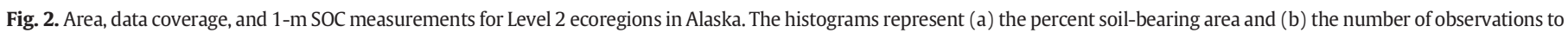
a 1-m depth within each ecoregion. Box plots for SOC observations (c) represent the $90 \%$ data intervals, inter-quartile ranges and medians. 


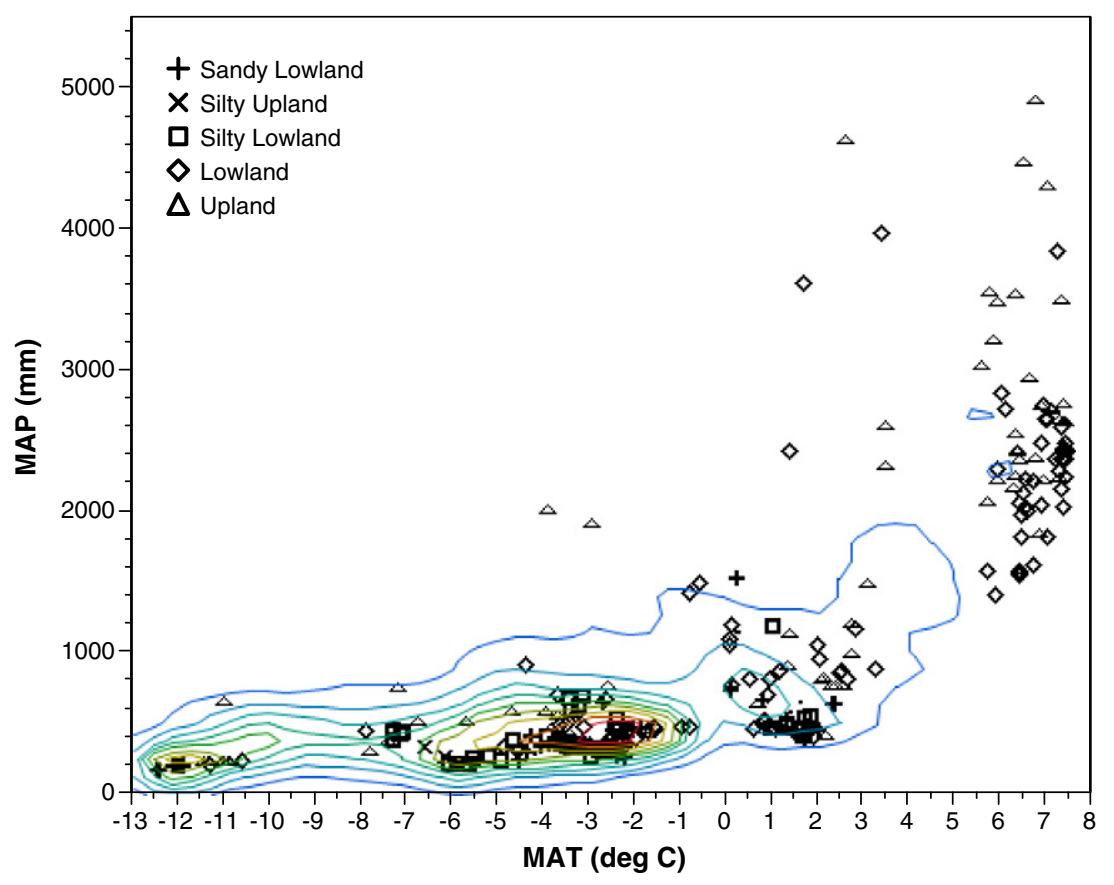

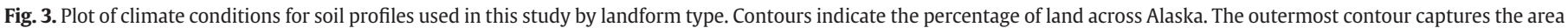
representing $90 \%$ of Alaska's soil bearing landscape while the innermost contour corresponds to $10 \%$ of the landscape (contour intervals of $10 \%$ ).

highest mean 1-m SOC was in the Arctic Tundra Uplands with $533 \mathrm{Mg} \mathrm{ha}^{-1}$ and the lowest was in the Intermontane Boreal Uplands with $86 \mathrm{Mg} \mathrm{ha}^{-1}$. The Arctic Tundra Uplands were also 2.5 and 2.2 times the mean SOC in Uplands of the Alaska Range Transition (210 $\mathrm{Mg} \mathrm{ha}^{-1}$ ), and Coastal Rainforests ( $240 \mathrm{Mg} \mathrm{ha}^{-1}$ ), respectively. Similarly, Sandy Lowlands of the Arctic Tundra $\left(511 \mathrm{Mg} \mathrm{ha}^{-1}\right)$ and

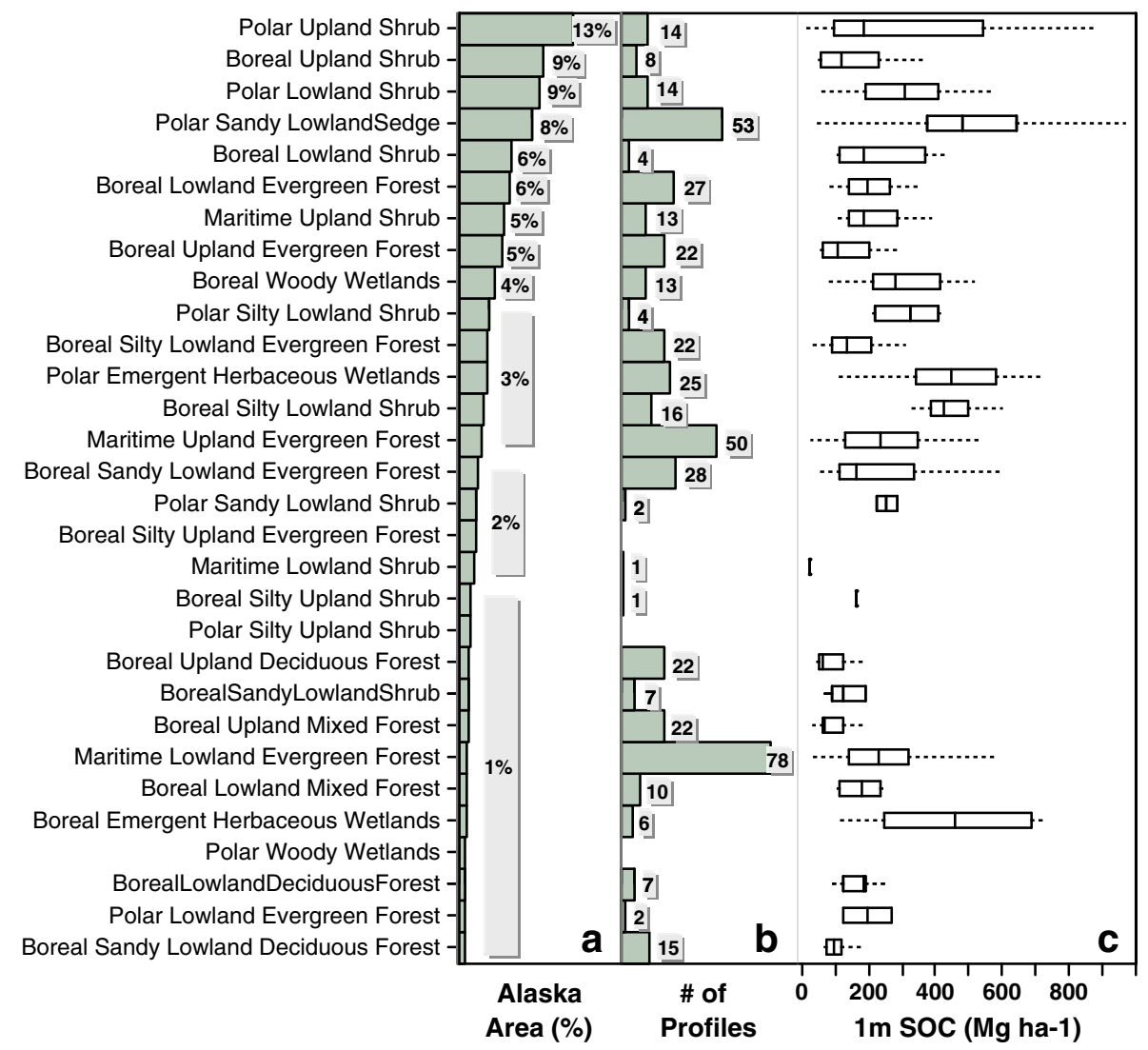

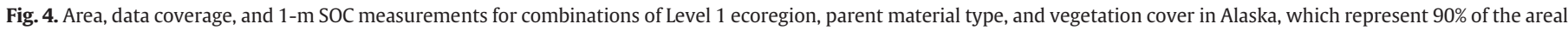

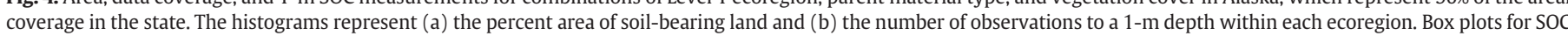
means (c) represent the $90 \%$ data intervals, inter-quartile ranges and medians. 
Table 1

Soil carbon means $\left(\mathrm{Mg} \mathrm{ha}^{-1}\right)$, standard deviations in parentheses, and sample numbers for various landforms and ecoregions in Alaska.

\begin{tabular}{|c|c|c|c|c|c|c|}
\hline \multirow[t]{2}{*}{ Level 2 Ecoregion (commoner) } & \multirow[t]{2}{*}{ Pool } & \multicolumn{5}{|l|}{ Landform } \\
\hline & & Upland & Lowland & Sandy lowland & Silty lowland & Wetland \\
\hline \multirow[t]{4}{*}{ Arctic Tundra ${ }^{\mathrm{b}}$ (Beaufort Coastal Plain, Brooks Foothills) } & Organic & $78(110) \mathrm{AB}$ & $39(12) \mathrm{AB}$ & 120 (117) A & n.d. & $81(101)$ \\
\hline & $50 \mathrm{~cm}$ mineral & $284(185) \mathrm{A}$ & 195 (67) A & $234(114) \mathrm{A}$ & n.d. & 216 (89) A \\
\hline & $1 \mathrm{~m}$ total & 533 (328) Aab & $328(160) \mathrm{Ab}$ & 511 (193) Aa & n.d. & $442(164) a b$ \\
\hline & $\mathrm{n}^{\mathrm{a}}$ & 14 & 13 & 47 & 0 & 25 \\
\hline \multirow[t]{4}{*}{ Intermontane Boreal (many) } & Organic & $21(25) \mathrm{B}$ & $49(27) \mathrm{AB}$ & $19(32) \mathrm{B}$ & $40(35)$ & $272(250)$ \\
\hline & $50 \mathrm{~cm}$ mineral & $57(40) \mathrm{B}$ & 121 (76) B & $72(78) \mathrm{B}$ & $92(61)$ B & 170 (168) B \\
\hline & $1 \mathrm{~m}$ total & $86(45) C$ & 194 (79) B & $113(98) \mathrm{B}$ & $152(88)$ B & $381(207)$ \\
\hline & $\mathrm{n}$ & 53 & 70 & 28 & 30 & 13 \\
\hline \multirow[t]{4}{*}{ Alaska Range Transition (Cook Inlet Basin) } & Organic & $46(67) \mathrm{A}$ & $32(13) \mathrm{B}$ & $96(178) \mathrm{A}$ & $33(11)$ & $38(44)$ \\
\hline & $50 \mathrm{~cm}$ mineral & $147(45) \mathrm{A}$ & $170(122) \mathrm{AB}$ & $194(72) \mathrm{A}$ & $190(65) \mathrm{A}$ & $135(48)$ \\
\hline & $1 \mathrm{~m}$ total & $210(88) \mathrm{B}$ & $216(123) \mathrm{AB}$ & $376(130) \mathrm{A}$ & $283(80) \mathrm{A}$ & $256(95)$ \\
\hline & $\mathrm{n}$ & 16 & 10 & 10 & 10 & 4 \\
\hline \multirow[t]{4}{*}{ Coastal Rainforests ${ }^{\mathrm{c}}$ (Alexander Archipelago) } & Organic & 77 (103) A & 105 (188) A & n.d. & n.d. & n.d. \\
\hline & $50 \mathrm{~cm}$ mineral & $181(108) \mathrm{A}$ & $170(96) \mathrm{AB}$ & n.d. & n.d. & n.d. \\
\hline & $1 \mathrm{~m}$ total & 240 (132) B & 258 (174) AB & n.d. & n.d. & n.d. \\
\hline & $\mathrm{n}$ & 66 & 71 & 0 & 0 & 0 \\
\hline
\end{tabular}

Different lower case letters indicate significant differences $(\mathrm{P}<0.05)$ between landform types of the same ecoregion. Different upper case letters indicate significant differences $(\mathrm{P}<0.05)$ between ecoregions of the same landform type.

a Samples $<5$ were omitted from comparisons.

b Excludes observations from the Brooks range for comparability across landform types.

c Excludes observations from the Alaska range for comparability across landform types.

Alaska Range Transition (376 $\mathrm{Mg} \mathrm{ha}^{-1}$ ) regions were 4.5 and 3.3 times higher than the Intermontane Boreal region $\left(113 \mathrm{Mg} \mathrm{ha}^{-1}\right)$. Also, the Silty Lowlands were 1.9 times higher in the Alaska Range Transition $\left(283 \mathrm{Mg} \mathrm{ha}^{-1}\right.$ ) than in the Intermontane Boreal $\left(152 \mathrm{Mg} \mathrm{ha}^{-1}\right)$. The Lowlands were only significantly different in their SOC content between the Arctic Tundra and Intermontane Boreal. In contrast, there were no differences among Arctic Tundra and Intermontane Boreal Wetlands.

Within ecoregions, the largest difference in 1-m SOC among landforms occurred in the Intermontane Boreal between the Wetlands (381 $\mathrm{Mg} \mathrm{ha}^{-1}$ ) and all other landforms, being 4.4, 3.4, 2.5, and 2.0 times larger than the Uplands, Sandy Lowlands, Silty Lowlands (152 $\mathrm{Mg} \mathrm{ha}^{-1}$ ), and Lowlands (194 $\mathrm{Mg} \mathrm{ha}^{-1}$ ), respectively (Table 1). Similarly, the Intermontane Boreal Lowlands were 2.3 and 1.7 times higher than the Uplands and Sandy Lowlands. No differences in SOC were observed in the Coastal Rainforest landforms. Sandy Lowlands of the Arctic Tundra were significantly higher than other Lowlands, but Sandy Lowlands were also spatially distributed towards the northern edge of Alaska where temperatures were colder.

\subsubsection{Partitioning SOC by ecosystem}

When 1-m SOC was partitioned by ecosystem (i.e. local-scale combinations of ecoregion, landform, and vegetation), there was more than a 10 -fold difference among means that was highly significant $(\mathrm{P}<0.0001)$ (Table 2). There were low sample numbers for some groups; however, dominant environments within specific ecoregions were still represented (see Fig. 4 for box plots of similar Level 1 ecoregion ecosystems). Mean 1-m SOC was highest in Arctic Tundra Sedge Uplands and Sandy Lowlands ( 729 and $519 \mathrm{Mg} \mathrm{ha}^{-1}$ ) and lowest in Intermontane Boreal White Spruce, Mixed Forest and Deciduous Forests (69, 74 and $81 \mathrm{Mg} \mathrm{ha}^{-1}$ ) (Table 2).

When holding ecoregion and landform constant, the largest and most significant $(\mathrm{P}<0.05)$ differences between vegetation types occurred in the Intermontane Boreal, where in the Sandy Lowlands Black Spruce (288 $\mathrm{Mg} \mathrm{ha}^{-1}$ ) and White Spruce (134 $\mathrm{Mg} \mathrm{ha}^{-1}$ ) were 3.1 and 1.5 times higher, respectively, than Mixed Forest (92 $\mathrm{Mg} \mathrm{ha}^{-1}$ ) (Table 2). Both the organic and mineral SOC pools contributed roughly equally to the higher SOC observed in Sandy Lowland Black Spruce compared to other Sandy Lowland vegetation types. Similar differences were observed between Upland Black Spruce and other species (Table 2). However, these differences were not significant and we note that only five black spruce observations were available for this comparison. In contrast, the Coastal Rainforests showed little change across Upland ecosystems except that Lowland Sitka Spruce $\left(248 \mathrm{Mg} \mathrm{ha}^{-1}\right.$ ) was 1.6 times higher than Lowland Mixed Forest (152 $\mathrm{Mg} \mathrm{ha}^{-1}$ ).

Some forest types that occur over a variety of landforms were compared by holding ecoregion and vegetation type constant. Both Deciduous and White Spruce types in the Intermontane Boreal had higher 1-m SOC in the Sandy Lowlands compared to the Uplands (Table 2). There were no significant differences among other landform and vegetation combinations, including all black spruce types.

\subsection{Factors affecting SOC accumulation}

\subsubsection{Climate and SOC interactions in uplands and lowlands}

Soil carbon contents changed dramatically, but non-linearly in Upland and Lowland landforms across a latitudinal gradient represented by selected ecoregions (Table 1 ; Fig. 5a,b). Concurrently, vegetation changed from sedges and shrubs to forest, reflecting warmer soil temperatures related to higher MAT (Fig. 5c) and GSL. Precipitation also increased steadily, until the Coastal Rainforest, where it increased sharply (Fig. 5d). The magnitude of SOC changes was greater in the Uplands than in the Lowlands. Indeed, the change was only significant between Intermontane Boreal and Arctic Tundra Lowlands for both the $1-\mathrm{m}$ and $50 \mathrm{~cm}$ mineral pools (Table 1 ).

\subsubsection{Climate and SOC interaction by ecosystem-boreal forest regression models}

Regression models were successful at showing that climate variables affect $50 \mathrm{~cm}$ mineral SOC (Table 3 ). However, the collinearity of several of the climate variables limits our interpretation of exactly which one is responsible for driving SOC changes. The Upland forests of the Intermontane Boreal and Alaska Range Transition are two contrasting ecoregions that comprise most of the Boreal dataset. The Intermontane Boreal has higher MST (Fig. 5c) and fire frequency, but lower GSL. The degree of continentality (i.e. MST-MWT) alone explained $69 \%$ of the variation of $50 \mathrm{~cm}$ mineral SOC and $46 \%$ in the 1-m SOC pool. In another model, GSL and MST explained $73 \%$ of the variation (Table 3). These relationships were consistent even when analyzed separately within each ecoregion where the GSL and MST model explained $30 \%$ and $42 \%$ of the variation in the Intermontane Boreal and Alaska Range Transition, respectively, with all parameters remaining significant $(\mathrm{P}<0.01$; not shown in Table 3$)$. Adding the logtransformed thickness of the organic layer to the first GSL and MST 
Table 2

Soil carbon means $\left(\mathrm{Mg} \mathrm{ha}^{-1}\right)$, standard deviations in parentheses, and sample numbers for various ecosystems, i.e. vegetation types by their specific landform and ecoregion.

\begin{tabular}{|c|c|c|c|c|c|c|}
\hline \multirow[t]{2}{*}{ Selected ecoregion } & \multirow[t]{2}{*}{ Landform } & \multirow[t]{2}{*}{ Veg type } & \multicolumn{3}{|c|}{ SOC pool $\left(\mathrm{MgC} \mathrm{ha}^{-1}\right)$} & \multirow[t]{2}{*}{$\mathrm{n}^{\mathrm{a}}$} \\
\hline & & & $1 \mathrm{~m}$ total & $50 \mathrm{~cm} \mathrm{~min}$ & Organic & \\
\hline \multirow[t]{6}{*}{ Arctic tundra } & \multirow[t]{2}{*}{ Upland } & Sedge & $729(302)$ & $305(102)$ & 88 (129) & 5 \\
\hline & & Dwarf shrub & $424(302)$ & $274(217)$ & $59(71)$ & 9 \\
\hline & \multirow[t]{2}{*}{ Lowland } & Dwarf shrub & $353(210)$ & $269(36)$ & $37(17)$ & 5 \\
\hline & & Shrub & $343(99)$ & $168(62)$ & $40(11)$ & 5 \\
\hline & \multirow{2}{*}{$\begin{array}{l}\text { Sandy low. } \\
\text { Wetland }\end{array}$} & Sedge & $519(191)$ & $236(116)$ & $123(118)$ & 45 \\
\hline & & Emergent wet. & $442(164)$ & $216(89)$ & $81(101)$ & 25 \\
\hline \multirow[t]{14}{*}{ Inter-montane boreal } & \multirow[t]{4}{*}{ Upland } & Deciduous & $81(46)$ B & $52(23)$ & $22(33)$ & 20 \\
\hline & & Mixed forest & $74(24)$ & $44(8)$ & $17(11)$ & 15 \\
\hline & & White spruce & 69 (16) B & 46 (12) B & $13(10)$ & 9 \\
\hline & & Black spruce & $121(56)$ & $85(54)$ & $39(35)$ & 5 \\
\hline & Lowland & Black spruce & $217(75)$ & $137(79)$ & $57(28)$ & 19 \\
\hline & \multirow[t]{4}{*}{ Sandy low. } & Deciduous & 99 (31) Aab & $59(34) \mathrm{b}$ & $14(16) \mathrm{b}$ & 13 \\
\hline & & Mixed forest & $92(31) b$ & $62(30) a b$ & $15(9) b$ & 21 \\
\hline & & White spruce & 134 (46) Aa & 84 (29) Aa & $12(24) \mathrm{b}$ & 16 \\
\hline & & Black spruce & $288(220) \mathrm{a}$ & $187(201) \mathrm{ab}$ & $86(65) a$ & 7 \\
\hline & \multirow[t]{3}{*}{ Silty low. } & Mixed forest & $117(66)$ & $64(39)$ & $30(30)$ & 6 \\
\hline & & White spruce & 106 (53) AB & 87 (86) AB & $30(24)$ & 7 \\
\hline & & Black spruce & $172(71)$ & $91(40)$ & $58(34)$ & 10 \\
\hline & \multirow[t]{2}{*}{ Wetland } & Woody wet. & $292(136)$ & $109(43)$ & $179(200)$ & 10 \\
\hline & & Emergent wet. & $676(55)$ & $382(314)$ & $582(92)$ & 3 \\
\hline \multirow[t]{7}{*}{ Alaska Range Transition } & \multirow[t]{2}{*}{ Upland } & Mixed forest & $188(108)$ & $121(25)$ & $65(110)$ & 6 \\
\hline & & White spruce & $224(37)$ & $167(29)$ & $28(6)$ & 4 \\
\hline & \multirow[t]{2}{*}{ Lowland } & Deciduous & $187(5)$ & $158(58)$ & $23(11)$ & 4 \\
\hline & & Mixed forest & $256(178)$ & 206 (159) & $33(6)$ & 7 \\
\hline & Silty low. & Mixed forest & $248(57)$ & $161(42)$ & $35(12)$ & 7 \\
\hline & \multirow[t]{2}{*}{ Wetland } & Woody wet. & 319 & 169 & 11 & 1 \\
\hline & & Emergent wet. & $235(105)$ & $153(4)$ & $60(60)$ & 3 \\
\hline \multirow[t]{5}{*}{ Coastal rainforest } & \multirow[t]{3}{*}{ Upland } & Shrub & $227(89)$ & $175(60)$ & $36(13)$ & 11 \\
\hline & & Mixed forest & $233(93)$ & $229(72)$ & $100(139)$ & 9 \\
\hline & & Sitka spruce & $245(147)$ & $173(121)$ & 87 (109) & 46 \\
\hline & \multirow[t]{2}{*}{ Lowland } & Mixed forest & $322(451)$ & $116(109)$ & $246(483)$ & 7 \\
\hline & & Sitka spruce & $152(47)$ & $116(109)$ & $63(22)$ & 63 \\
\hline
\end{tabular}

Different lower case letters indicate significant differences between vegetation types of the same landform and ecoregion.

Different upper case letters indicate significant differences between landforms of the same vegetation type and ecoregion.

a Samples $<5$ were omitted from comparisons.

regression improved the model fit (Table 3), where the parameter was positive and highly significant $(\mathrm{p}=0.0053)$.

Models with MAP, MSP and MWP did not improve the model $\mathrm{R}^{2}$ as GSL and MST were always the most significant variables models. Nevertheless, a highly significant model with GSL and MAP, with both parameters positive, still explained $64 \%$ of the variation (Table 3 ). Similar Lowland models were found, but they were always weaker than the Upland models (adj. $\mathrm{R}^{2}$ near 0.1 ). Adding GSL or MST interaction terms into the regression models above did not improve the model fit or achieve greater model significance.

\subsubsection{Aspect}

Differences in 1-m SOC between aspect classes were largest within the Arctic Tundra and Coastal Rainforests (Table 4). Soil profiles located in Arctic Tundra NE aspects (565 $\mathrm{Mg} \mathrm{ha}^{-1}$ ) in Sandy Lowlands contained 1.3 times more SOC than those located in NW/SE aspects (427 $\mathrm{Mg} \mathrm{ha}^{-1}$ ). Further, also for Arctic Tundra Sandy Lowlands, folded aspect was significantly correlated with $50 \mathrm{~cm}$ mineral SOC $(\mathrm{P}=0.0006)$ and explained $22 \%$ of the variation in this pool. NE (302 $\mathrm{Mg} \mathrm{ha}^{-1}$ ) and NW/SE (291 Mg ha ${ }^{-1}$ ) aspects were both approximately 1.7 times higher than SW aspects ( $174 \mathrm{Mg} \mathrm{ha}^{-1}$ ) in the Coastal Rainforest Lowlands. The largest difference observed in the Intermontane Boreal was in the Uplands, where SW aspects $\left(121 \mathrm{Mg} \mathrm{ha}^{-1}\right)$ were higher than NW/SE aspects ( $77 \mathrm{Mg} \mathrm{ha}^{-1}$ ) by a factor of 1.6 , and was due mostly to changes in the mineral SOC pool. No other significant differences across aspects were observed in the Uplands of other ecoregions. This is despite the fact that a large variation in solar radiation occurs in the Uplands and may suggest that sampling was too limited across aspect types (Table 4).

\subsubsection{Permafrost}

Although the presence and depth of permafrost and active-layer depth (ALD) were incomplete, at least one comparison was possible within a single vegetation type: black spruce forests. Soil organic carbon was 1.4 times higher $(\mathrm{P}<0.05)$ under black spruce with permafrost present in the top $1-\mathrm{m}$ of soil $\left(262 \mathrm{Mg} \mathrm{ha}^{-1}\right)$ than black spruce without permafrost ( $186 \mathrm{Mg} \mathrm{ha}^{-1}$ ). This difference was apparently due to higher SOC in the organic layer because there was no significant difference in the $50 \mathrm{~cm}$ mineral SOC pool $(P>0.1)$. From limited ALD data, mean Boreal ALD was much greater $(69 \mathrm{~cm})$ than Polar soils $(44 \mathrm{~cm})$ $(\mathrm{P}<0.0001)$.

\subsubsection{Fire}

There were no profiles located in areas that had been burned within the last 65 years outside the Intermontane Boreal region. Burned profiles were lower in 1-m SOC than unburned, but only for Sandy Lowland (53 vs. $141 \mathrm{MgC} \mathrm{ha}^{-1} ; \mathrm{P}<0.0001$ ) and Upland (66 vs. $93 \mathrm{MgC}$ ha-1; $\mathrm{P}<0.05$ ) landforms. In Sandy Lowlands, both organic layer SOC and $50 \mathrm{~cm}$ mineral SOC were significantly lower in burned than unburned profiles $(\mathrm{P}<0.01)$. However, in Uplands, only organic layer SOC of burned profiles was significantly lower than unburned $(P<0.01)$, while $50 \mathrm{~cm}$ mineral SOC showed no difference $(P>0.1)$.

\section{Discussion}

\subsection{Representativeness and data gaps}

The collaborative data collection effort used in this study resulted in a generally representative dataset of many of Alaska's soils by area. There was generally good coverage of the Uplands and Lowlands 

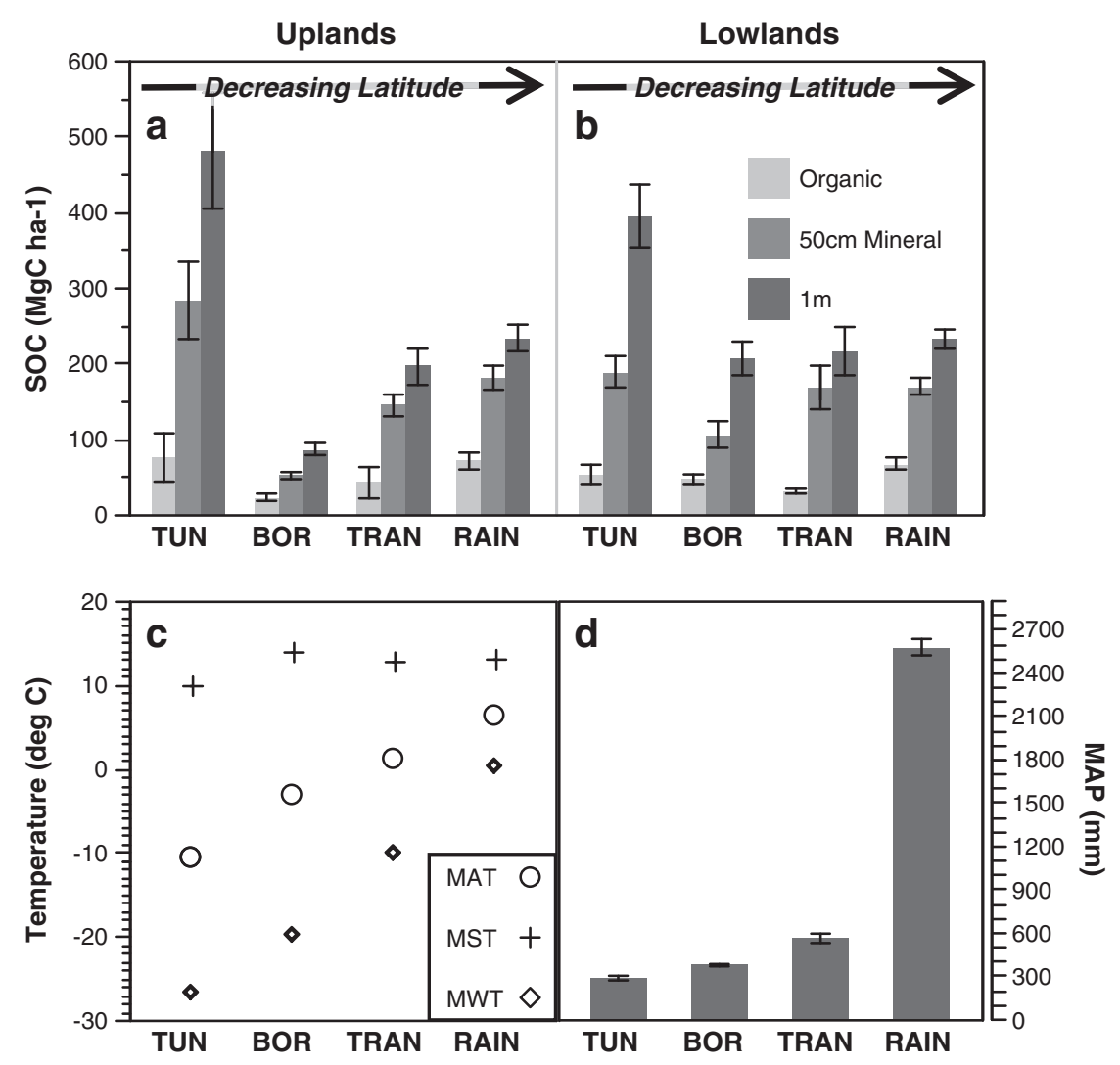

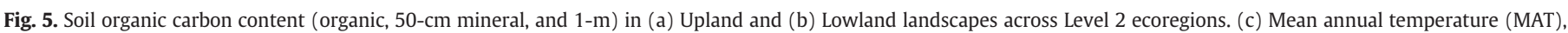

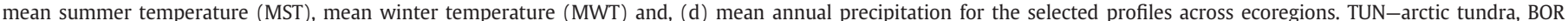

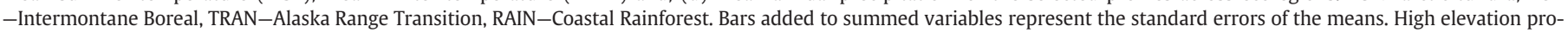
files in the Brooks and Alaska ranges, and profiles under forests $<65$ years old, were removed for comparability.

(of Rocky or Variable soil parent materials) which cover $62 \%$ of the state. However, our findings suggest that areas of highest SOC content and highest SOC variability, i.e. permafrost and wetland locations (Rapalee et al., 1998; Tarnocai et al., 2009; Turetsky et al., 2005; Zimov et al., 2006), are still under-sampled. More precise delineation of parent material type and extent than was used in this study is needed to extrapolate where permafrost occurs and at what depth, especially in the Intermontane Boreal. Knowing permafrost depth and spatial extent would facilitate an understanding of how permafrost is distributed in relation to SOC densities $\left(\mathrm{g} \mathrm{cm}^{-3}\right)$ within the soil profile. It remains uncertain how sensitive deeper than 1-m SOC pools are to future climate changes (McGuire et al., 2009; Schuur et al., 2009; Tarnocai et al., 2009). Given

Table 3

Linear regression models of SOC distribution for boreal upland forests in the 0 to $50 \mathrm{~cm}$ mineral soil (depth below the organic horizon and mineral horizon interface).

\begin{tabular}{lrrrrrr}
\hline Model terms & $\begin{array}{l}\text { Coefficients } \\
\text { (std error) }\end{array}$ & df & $\begin{array}{l}\text { Model } \\
\text { p-value }\end{array}$ & RMSE & adj. R & AICc \\
\hline MST-MWT & $-6.96(0.64)$ & 53 & $<0.0001$ & 25.79 & 0.69 & 518.0 \\
GSL & $1.91(0.20)$ & 52 & $<0.0001$ & 24.12 & 0.73 & 511.9 \\
MST & $-16.24(2.56)$ & & & & & \\
GSL & $1.92(0.19)$ & 51 & $<0.0001$ & 22.55 & 0.76 & 505.9 \\
MST & $-12.37(2.74)$ & & & & & \\
lnThick & $12.12(4.16)$ & & & & & \\
GSL & $1.73(0.24)$ & 52 & $<0.0001$ & 27.82 & 0.64 & 527.7 \\
MAP & $0.17(0.04)$ & & & & & \\
\hline
\end{tabular}

Profiles under stands $<65$ years old omitted.

MST-mean summer temperature, MWT-mean winter temperature, GSL-growing season length, Thick-thickness of organic layer, MAP-mean annual precipitation. the potential ecosystem consequences of permafrost thaw, the spatial distribution and quantification of permafrost SOC remains an important knowledge gap (Davidson and Janssens, 2006; Hinzman et al., 2006; Schuur et al., 2008).

The three-fold differences in SOC observed in the Sandy Lowlands under different vegetation types indicate the high spatial variability of soil drainage classes within lowland areas. Wetlands, peatlands, and other adjacent lowlands are complex and dynamic environments where land cover, permafrost distribution, and drainage change dramatically within small spatial scales (Turetsky et al., 2005). These environments are further impacted by fire which can change soil properties quickly (Harden et al., 2000, 2006; Swanson, 1996). If fire frequency increases in Alaska due to future climate warming (Balshi et al., 2009), alterations in land cover and soil drainage (e.g. thermokarst or talik development) will likely affect Alaska's SOC contents and spatial distributions (Harden et al., 2000; Jorgenson and Osterkamp, 2005; Jorgenson et al., 2001). Further sampling in these areas will help reduce the uncertainty in the fate of lowland SOC in response to fires and other climate-driven factors.

The distribution of roads in Polar and Boreal Alaska has made it possible to sample soils over latitudinal gradients that cross a variety of climate regimes, landforms and vegetation types (Fig. 1). However, noticeably missing are observations across longitudinal gradients that are more representative of continental effects on climate regimes. The importance of continentality is partly indicated by the negative relation of MST-MWT and SOC in the Upland forests found in this study (Table 3). The north-south distribution of observations is less ideal because interior Alaska is bounded by the Brooks and Alaska Ranges which separate different climate patterns. For example, MAT and MAP tend to be more strongly positively correlated to each other in the Arctic Tundra than in the Intermontane Boreal and Bering Tundra. Although the Arctic Tundra and Bering Tundra are similar in vegetation composition and 
Table 4

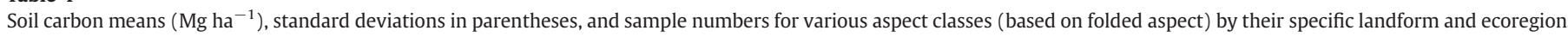

\begin{tabular}{|c|c|c|c|c|c|c|}
\hline \multirow[t]{2}{*}{ Ecoregion } & \multirow[t]{2}{*}{ Landform } & \multirow{2}{*}{$\begin{array}{l}\text { Veg } \\
\text { type }\end{array}$} & \multicolumn{3}{|c|}{ SOC pool $\left(\mathrm{MgC} \mathrm{ha}^{-1}\right)$} & \multirow[t]{2}{*}{$\mathrm{n}^{\mathrm{a}}$} \\
\hline & & & $1 \mathrm{~m}$ total & $50 \mathrm{~cm} \mathrm{~min}$ & Organic & \\
\hline \multirow[t]{5}{*}{ Arctic tundra } & \multirow[t]{2}{*}{ Upland } & NW/SE & 527 (167) & $268(90)$ & $62(67)$ & 6 \\
\hline & & SW & $531(452)$ & $279(248)$ & $113(152)$ & 5 \\
\hline & Lowland & $\mathrm{NE}$ & $379(111)$ & $197(63)$ & $44(12)$ & 11 \\
\hline & \multirow[t]{2}{*}{ Sandy low. } & NE & 565 (211) a & 282 (111) a & $100(126)$ & 29 \\
\hline & & NW/SE & 427 (124) b & $175(80) \mathrm{b}$ & $138(89)$ & 17 \\
\hline \multirow{12}{*}{ Inter-montane boreal } & \multirow{3}{*}{ Upland } & NE & 99 (29) ab & 55 (19) ab & $37(41) \mathrm{a}$ & 9 \\
\hline & & $\mathrm{NW} / \mathrm{SE}$ & 77 (46) b & 49 (36) b & $19(27) \mathrm{b}$ & 38 \\
\hline & & SW & $121(38) \mathrm{a}$ & $101(57)$ a & $21(12) a b$ & 6 \\
\hline & \multirow{3}{*}{ Lowland } & $\mathrm{NE}$ & $160(68)$ & 74 (29) & $36(21)$ & 6 \\
\hline & & NW/SE & $203(78)$ & $127(87)$ & $46(27)$ & 18 \\
\hline & & SW & 203 (103) & $117(51)$ & 60 (29) & 4 \\
\hline & \multirow[t]{3}{*}{ Sandy low. } & $\mathrm{NE}$ & $161(98) \mathrm{a}$ & $112(66) a b$ & $46(36) \mathrm{a}$ & 6 \\
\hline & & NW/SE & 109 (121) b & 67 (91) b & $20(32) a b$ & 40 \\
\hline & & SW & $108(35) \mathrm{a}$ & $74(46)$ a & $14(27) \mathrm{b}$ & 24 \\
\hline & \multirow[t]{3}{*}{ Silty low. } & $\mathrm{NE}$ & 141 (109) & $93(76)$ & $40(31)$ & 10 \\
\hline & & NW/SE & $151(80)$ & 89 (55) & $37(28)$ & 14 \\
\hline & & SW & $175(77)$ & 97 (35) & $49(46)$ & 6 \\
\hline \multirow{6}{*}{ Alaska Range Transition } & \multirow{2}{*}{ Upland } & $\mathrm{NE}$ & $243(68)$ & $181(32) \mathrm{a}$ & $35(23)$ & 7 \\
\hline & & SW & $197(110)$ & 139 (58) b & $68(108)$ & 6 \\
\hline & \multirow[t]{2}{*}{ Lowland } & NW/SE & $194(46)$ & $130(49)$ & $38(15)$ & 6 \\
\hline & & SW & $232(163)$ & $199(146)$ & $28(11)$ & 9 \\
\hline & Sandy low. & NW/SE & $365(121)$ & $165(25)$ & $152(250)$ & 6 \\
\hline & Silty low. & NW/SE & $271(76)$ & $185(66)$ & $34(11)$ & 9 \\
\hline \multirow[t]{6}{*}{ Coastal rainforest } & \multirow[t]{3}{*}{ Upland } & $\mathrm{NE}$ & $242(81)$ & $179(57)$ & $71(104)$ & 9 \\
\hline & & NW/SE & $211(128)$ & 145 (107) & 105 (133) & 18 \\
\hline & & SW & $253(143)$ & 197 (116) & 70 (89) & 39 \\
\hline & \multirow[t]{3}{*}{ Lowland } & $\mathrm{NE}$ & 302 (257) a & 170 (77) ab & $134(310)$ & 21 \\
\hline & & NW/SE & 291 (113) a & $200(96)$ a & $123(144)$ & 28 \\
\hline & & SW & 174 (102) b & 135 (102) b & $61(23)$ & 22 \\
\hline
\end{tabular}

Different lower case letters indicate significant differences $(\mathrm{P}<0.05)$ between aspect classes of the same landform and ecoregion.

a Samples $<5$ were omitted from comparisons.

parent material, the Bering Tundra is much warmer due to higher solar radiation and a longer growing season. Thus, there is reason to be cautious about assuming that SOC contents in the Arctic Tundra represent SOC for the Bering Tundra.

Despite the vast coverage of shrubby land covers across Alaska (56\%; Fig. 4), this vegetation type was sparsely sampled. Shrub cover in the Boreal and Polar regions has expanded in recent decades (Sturm et al., 2001; Tape et al., 2006) and changes in their spatial distributions may be related to permafrost thaw and belowground carbon losses (Harden et al., 2008; Wilmking et al., 2006). One reason for the relatively low number of observations may be that alpine shrubs are typically less accessible as they often occur at higher elevation and further from roads. However, there can be substantial SOC content in moderately sloped alpine shrub terrain. The northern foothills of the Alaska Range, for example, have a mean 1-m SOC content of $493 \mathrm{Mg} \mathrm{ha}^{-1}$ (Schuur et al., 2009). New SOC observations from alpine shrub and tundra landscapes, including thinner soils as endpoints, would improve our understanding of pedogenesis, shrub encroachment, and afforestation processes across climate gradients.

\subsection{Soil forming factor controls on SOC accumulations}

Our results confirm that air temperature is the dominant control on SOC distribution across Alaska (Ping et al., 1997, 2008b). Previous global and continental scale studies also support that temperature has a negative or non-linear relation to SOC (Amundson, 2001; Guo et al., 2006; Post et al., 1982; Wynn et al., 2006). Temperature-related permafrost and cryoturbation processes enhanced the $1-\mathrm{m}$ SOC content in Arctic Tundra soils so that they were more than double the SOC of the other ecoregions. Various physical processes can account for this. Surface SOC can be subducted into the soil matrix during seasonal freezing and thawing until it reaches the top of the permafrost table where it is essentially protected from mineralization, owing to lower decomposition at freezing temperatures (Ping et al., 2008b). The thawing of underlying ice-rich permafrost can also cause displacement of soil layers with differing water contents and densities (Swanson, 1996).

Precipitation also plays an important role in SOC accumulation. While SOC increases with increasing temperature and precipitation at lower latitudes in Alaska (cf., Callesen et al., 2003), SOC decreases with increasing temperature at higher latitudes, especially in mineral soils (Fig. 5). In warmer and wetter environments such as the Coastal Rainforest, higher productivity leads to higher organic carbon inputs into the soil matrix. The soils at these locations are also more weathered (as evidenced by their higher clay contents and illuvial horizons; data not shown) which allows for greater stabilization of SOC in the mineral soils.

Considerable variability of SOC within ecoregions can be attributed to the effects of changing topography and soil drainage (Callesen et al., 2003). Previous studies have noted differences in SOC distributions for various landforms, vegetation types, and aspects in Alaska (Michaelson et al., 1996; Ping et al., 2005, 2008b; Troth et al., 1976; Van Cleve et al., 1983, 1993, 1996). The results of this study confirm that improved drainage enhances air temperature effects on soil decomposition and SOC accumulation while impeded drainage diminishes temperature effects. For example, the difference in SOC between the Arctic Tundra and Intermontane Boreal regions for the Uplands was more than twice the difference observed for Lowlands (Table 1; Fig. 5). The impeded drainage at Lowland sites in both ecoregions is partially caused by the presence of permafrost. Soil moisture dampens the seasonal and diurnal amplitude of air temperatures, and plant production and decomposition are highly sensitive to such topographic attributes (e.g. Davidson et al., 1998). Similarly, it appears that impeded drainage was the reason that the Lowlands of the Intermontane Boreal were not very different from the Lowlands of the Coastal Rainforest, whereas for the Uplands the difference was almost three-fold (Table 1; Fig. 5). 
Additional controls on SOC accumulation in Alaska, both directly and indirectly related to climate, include interactions of physical >and biotic processes. For example, the $50 \mathrm{~cm}$ mineral SOC pool in the Intermontane Boreal region was substantially lower than in other ecoregions, even when our comparisons control for the effects of topography and soil drainage. One explanation for this is that black spruce at poorlydrained sites, in addition to having low productivity, also have roots that are largely constrained to the organic layer, limiting root inputs into the mineral soil (Bonan and Shugart, 1989; Viereck et al., 1983). Further, Lowland black spruce forests typically lack cryoturbation, and therefore exhibit lower mineral SOC content, whereas this process is known to occur on north-facing upland and toeslope soils (Ping et al., 2005). Our dataset has relatively few north-facing profiles under black spruce $(n=6)$ which, if accounted for, may increase our estimate of mineral SOC at Upland and Lowland locations. Additionally, within the Intermontane Boreal SOC was higher in locations with permafrost than in locations without in black spruce forests. This confirms similar findings in Alaska by Harden et al. (2006) and Ping et al. (2010) which showed that black spruce forest stands with permafrost were 1.6 times higher in SOC than non-permafrost stands.

Seasonal climatic and biotic interactions may also lower Upland SOC pools of the Intermontane Boreal in several ways. The Intermontane Boreal is a composite of two neighboring yet contrasting soil environments: decomposition-controlled frozen soils to the north (Arctic Tundra) and soils influenced more by plant inputs to the south (Alaska Range Transition). Cumulative fire effects or drought stress (Barber et al., 2000) may be associated with higher MST (Fig. 5) and limit plant growth and organic inputs to soils. Alternatively, both net primary production and decomposition can increase with higher MST because boreal forest productivity is often limited by nutrient release from organic matter mineralization, which increases with soil temperature when water is not limiting. This may be especially true in moderately well-drained soils where soil moisture is optimal for microbial decomposition and plant growth. Indeed, regression models of the Upland forest showed a decrease in mineral SOC with higher MST (Table 3), which may suggest that decomposition outstrips production at more mesic sites. Additionally, Kane and Vogel (2009) found that mineral SOC decreased as soil growing degree days (and productivity) increased in black spruce forests of Interior Alaska.

Importantly, a literal interpretation of the models in Table 3 suggests that if GSL increases substantially ( $>20$ days) SOC in mineral soils will increase. Climate regimes of higher GSL and MAP may allow for higher productivity, higher organic inputs and, therefore, higher SOC. A situation of increasing SOC may also occur with higher MST and GSL if soil temperatures stabilize due to the insulation of thicker organic layers, but productivity still increases (Table 3 ). However, increases in net primary production and litter layer inputs from increasing GSL and MAP are also likely to increase nutrient mineralization rates in the surface organic soil layers, affecting bryophyte proliferation and reducing organic layer depths (cf., Mack et al., 2004; Oechel and Van Cleve, 1986). A reduction in organic layer depths (e.g. the lnThick model; Table 3) may lead to greater thermal conductance to deeper mineral soil layers and enhanced soil $\mathrm{C}$ mineralization. Therefore, without considering the effects of fire, it is possible that Boreal forest mineral SOC could respond both positively and negatively to warmer temperatures where sometimes productivity and sometimes decomposition acts as the dominating control. The response will largely depend on concurrent alterations of soil drainage and the net influence on soil moisture status, plant growth, and soil microbial activity.

Fire is a major disturbance of soil properties and vegetation distributions in the Intermontane Boreal (Kasischke et al., 2002; Yarie, 1981). Fires affect mineral SOC pools by reducing organic layer depth and degrading permafrost, thereby increasing soil temperature, decreasing soil moisture, and increasing $\mathrm{CO}_{2}$ flux (O'Donnell et al., 2009; O'Neill et al., 2002; Viereck et al., 1983). Combustion represents a significant loss vector for $\mathrm{C}$ in Intermontane Boreal systems, on the order of 30 to
$60 \%$ of NPP over millennial timescales (Harden et al., 2000) and there may be a cumulative long-term effect on SOC which results from frequent burning of material that would otherwise be stabilized in the soil matrix. For example, Fan et al. (2008) simulated decreases of 8 to $78 \%$ in SOC over hundreds of years of repeated fires in Alaskan black spruce stands. These scenarios are complicated, however, by existing variable drainage patterns where wetter lowlands soils can reduce the impact of fire (cf., Harden et al., 2001). Our analysis of Sandy Lowland soils (i.e., floodplains) indicated that these predominantly well drained locations are the most affected by fire, apparently causing a 2.7 fold decrease in 1-m SOC. Upland SOC pools are also affected, but apparently more so in the organic layer than in the mineral.

It is difficult to separate fire frequency and seasonal temperature effects on SOC pools of the Intermontane Boreal because they co-vary. Perhaps a useful indicator of these interactions is the MST-MWT variable, where large values indicate higher continentality. Continentality has been associated with fire return interval in Eurasion boreal forests (Sannikov and Goldammer, 1996) and is negatively correlated with MAP in our data set. The interactions of climatic, biotic, and disturbance effects within the Intermontane Boreal may explain why SOC was lower here compared to other ecoregions.

A conceptual equilibrium model of SOC content with Inputs $(I)$ and Decomposition $(k)$ across ecoregions helps to summarize the temperature effects on SOC distribution for Uplands (Table 1; Fig. 6). For SOC in seasonally unfrozen and non-cryoturbated soils, $k$ increases and draws down the SOC pool with increasing MAT. Meanwhile, $I$ also increases with MAT, but not enough to balance SOC losses from the temperature effect on $k$. Similarly, in addition to the physical mixing of organic rich soils to the deeper profile, the $k$ term dominates the $I$ term in Polar regions. Although a little more than half of the total SOC pool is contained in cryoturbated and permafrost horizons in the Arctic Tundra, the role of cryoturbation over this gradient remains unclear (Bockheim, 2007; Michaelson et al., 1996).

As MAT further increases along the latitudinal gradient the importance of both the $I$ and $k$ terms converge in the Intermontane Boreal (Fig. 6). Permafrost distribution becomes spatially uneven and occurs deeper so that less SOC is permanently frozen. In some cases $k$ is the dominant control and further draws down the pool in response to

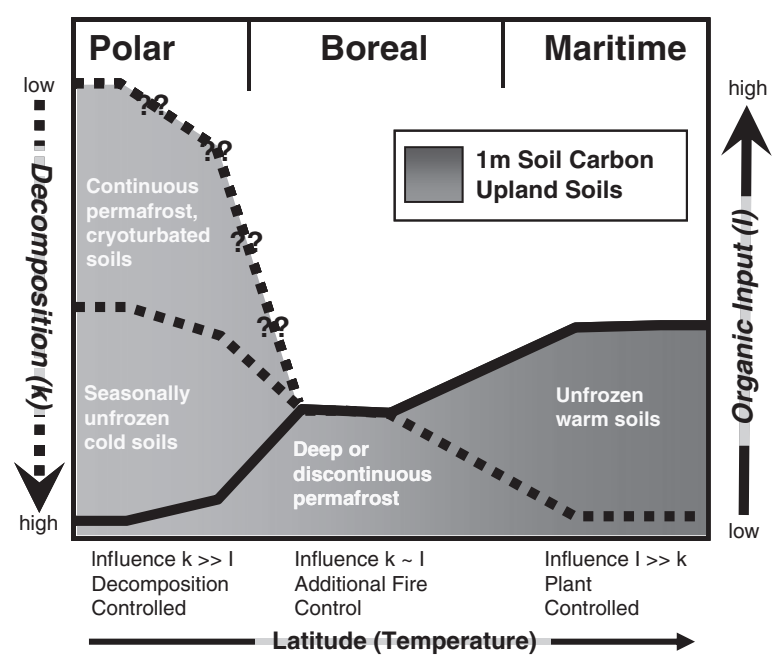

Fig. 6. Conceptual equilibrium model of the relative controls on soil carbon content based on Upland data from Table 1. The darkened area represents the total soil carbon content to a 1-m depth and gets darker as soils become warmer and thaw. The dotted lines correspond to the value of the decomposition factor, $k$, on the left axis (reversed). The solid lines correspond to the value of the organic inputs factor, $I$, on the right axis. The question marks indicate the poor comparability of Polar cryoturbated pools to other ecoregion soil carbon pools and its uncertainty in response to temperature change. Relative changes in SOC content $\left(\mathrm{Mg} \mathrm{ha}^{-1}\right)$ represented by the darkened areas over the latitude gradient are roughly to scale. 
higher decomposition (high MST) in moderately well-drained areas where productivity is low (low GSL) and/or fires are common. In other areas the relative influence of $I$ and $k$ roughly cancel each other out. Still other locations have more favorable GSL, less extreme MST, and perhaps fewer fires, allowing an increase in the SOC pool due to higher productivity relative to $k$. In the Boreal and Maritime regions where MAT $>0$ (and GSL is higher) SOC pools benefit from high productivity and low fire occurrence. Although $k$ increases, $I$ also increases until the equilibrium is reached for these climate conditions (about $230 \mathrm{Mg} \mathrm{ha}^{-1}$ ). Additionally, organic carbon is more likely to be stabilized in the mineral soils of the Maritime region and biotic and climatic influences result in greater development of parent material. Where drainage is limited, i.e. the Lowlands, these climate-related interactions are somewhat muted or absent. Similarly, local-scale drainage that is influenced by the presence of permafrost and cryoturbation, i.e. northfacing slopes, will be wetter and therefore affected less by these climate-fire interactions in the Boreal.

\subsection{Implications of future climate change effects on soil carbon pools}

Downscaled future climate projections for Alaska (5 model composite; Scenarios Network for Alaska Planning, http://www.snap.uaf.edu/) suggest that MAT may increase by $3.5,3.2$, and $2.4^{\circ} \mathrm{C}$ from 2009 to 2069 for the Polar, Boreal, and Maritime regions, respectively. Over the same interval, MAP is projected to increase by 70,40 , and $170 \mathrm{~mm}$ for the Polar, Boreal, and Maritime, respectively. Historic data from Fairbanks, AK also show that MAT has increased by $1.4^{\circ} \mathrm{C}$ over 100 years, but without any significant changes in MAP (Wendler and Shulski, 2009). Should Polar landscapes become more Boreal-like, experiencing higher MST's and fire frequencies, then drainage patterns will adjust accordingly with the result of potentially lowering SOC. Further, lower SOC could result if MAP does not increase in tandem with MAT, leading to higher evapotranspiration and drier soils. Conversely, should some Boreal soils for some reason experience longer growing seasons and either higher precipitation or altered drainage that favors wetter soils, then some soils would potentially increase in SOC if soil temperature remained unchanged. Perhaps most important, therefore, is how future climate change may alter soil moisture patterns, as topographic and parent material effects were demonstrated to ameliorate or exacerbate the effects of temperature on SOC storage (Fig. 5; see also Davidson and Janssens, 2006). Although this study did not focus on the future timing and magnitude of SOC changes in Alaska, a sense of the spatial extent and importance of soil drainage can be inferred. We note that the ecoregions represented in this study account for almost three quarters of Alaska (Fig. 2). More detailed quantification of the overall changes is best left to spatially explicit process-based ecosystem models. Modeling efforts may benefit from considering the variations in SOC for different landforms and vegetation types presented in this study.

The results of this study confirm that Alaska's SOC pool is very large and has important implications for $C$ accounting within the United States and North America, if not globally. For example, when we estimated mean $1-\mathrm{m}$ SOC content in the Arctic Tundra (372 $\mathrm{Mg} \mathrm{ha}^{-1}$; weighted by landform area) it was similar to one study's "North American Arctic" estimate (348 $\mathrm{Mg} \mathrm{ha}^{-1}$; Ping et al., 2008a,b), but higher than another study's global "Tundra" estimate (218 $\mathrm{Mg} \mathrm{ha}^{-1}$; Post et al., 1982). Additionally, Arctic Tundra SOC was 27 and 7 times higher than estimates for "Warm desert" ( $14 \mathrm{Mg} \mathrm{ha}^{-1}$ ) and "Tropical woodland and savanna" (54 $\mathrm{Mg} \mathrm{ha}^{-1}$ ), respectively (Post et al., 1982). It should be noted that such large scale comparisons can only be done imperfectly and with very high uncertainty because of different approaches to calculating both point and regional scale estimates of SOC. In general, there is a great need for reports of SOC to use enhanced data sets that not only capture site variability but that also consistently derive values in ways that minimize uncertainties from measurements and extrapolations to larger scales.

\section{Conclusions}

The soil carbon database used in this study was created as a resource for investigations into the importance of Alaskan soils in global climate change. From the database we have identified data gaps that limit our ability to scale up observational data and compare them to ecosystem model outputs. Other landforms and vegetation types that contain lower SOC, such as Upland shrubby landscapes, should not be ignored if their areal coverage may result in the accumulation of significant SOC stocks. Samples that fill in the longitudinal change in SOC from the Bering Taiga region to the Intermontane Boreal will also help to assess whether SOC changes over climatic gradients follow expected patterns, or if they deviate, and why. Finally, as the database grows to include more data from SOC in wetlands and permafrost for a variety of ecosystems, our understanding of SOC response to climate change will continue to improve.

Despite data gaps, it is clear that because most of Alaska's soils occur over a wide range of MAT under $0{ }^{\circ} \mathrm{C}$, that MAT exerts the first order effect on SOC spatial distribution across the state. Additionally, it is clear that the degree of climatic influence on SOC pools is variable among landforms of different relief and texture related to parent material. Adding to this complexity are additional controls of aspect, permafrost presence, and stand age that interact in non-linear patterns. Some basic inferences about how seasonal climate and disturbance affects SOC pools can be drawn by comparing ecoregions. Intermontane Boreal SOC content is lower than the other regions probably because of its continental climate that results in harsh winters, short growing seasons, low MAP, high MST, and high fire frequencies. As a conceptual model, the Intermontane Boreal is the transition between SOC pools which are dominated by physical and abiotic processes (i.e., cryoturbation and permafrost) and SOC pools that increase due to biotic factors related to higher organic inputs (i.e., productivity).

Determining the balance of carbon losses and gains from soils at high-latitudes, and their potential climatic feedbacks, depends to a large degree on how accurately the spatial heterogeneity of SOC pools can be scaled up and applied in global climate models. In this first order assessment of spatial heterogeneity in SOC pools across three very different high-latitude climatic regimes, we have aimed to discretely quantify SOC pools according to different ecoregion, landform, and ecosystem types. Our results suggest that the response of SOC pools to climate changes will not be of the same magnitude, and perhaps not even the same direction, for all high-latitude soils. Patterns of SOC accumulation in relation to upland and lowland ecosystems should be carefully considered in the modeling of terrestrial carbon cycling and the prediction of the future balance of carbon in Alaska and abroad. These issues deserve special attention given the enormous amount of carbon contained in high-latitude soils and their role in the global carbon cycle.

\section{Acknowledgements}

This assessment, and the workshop which led to the creation of the soil carbon database used in the assessment, was sponsored by the U.S. Geological Survey funded research on "Assessing the Role of Deep Soil Organic Carbon in Interior Alaska: Data, Models, and Spatial/Temporal Dynamics". The help of Deb Agarwal and Catharine Van Ingen from Lawrence Berkeley National Labs and Microsoft Research were essential for the creation and logistical support of the soil carbon database. We also acknowledge the very helpful reviews given by Bronwen Wang, Shuguang Liu, Ingeborg Callesen and one anonymous reviewer.

\section{Appendix 1. Gap-filling procedure}

Negative exponential models that predict bulk density from \%C were applied for missing data in all mineral soil horizons except arctic soils (Appendix Table 1). There were some rare cases when samples had 
bulk density data available but not \%C and were gap-filled using a modified equation (Eq. 3b). Models of SOC or bulk density were better fit when the horizon designation was known (Eqs. 4-6). When there was no horizon designation, and the horizon was only known to be organic $\left(S O C_{O}\right)$ or mineral $\left(B D_{\min }\right)$, then general models were applied (Eqs. 3a, 9). Frozen mineral soil bulk density of mainly Boreal profiles was predicted separately and was not distinguished by horizon designation (Eq. 7). In contrast to bulk density measurements of mineral soils, bulk density in organic soils was not well-predicted by nonlinear models of \%C. The best approach in this case proved to be the direct prediction of SOC content from horizon thickness, Th, using a weighted least squares regression and by horizon designation (Eqs. 10-12).

Adjustment equations were applied to bulk density and organic carbon concentration measurements from the National Cooperative Soil Survey (NCSS) in order to make them comparable to other datasets. Bulk density measurements by the NCSS were done by the clod method, $B D_{\text {clod }}$ (Soil Survey, 1996) whereas all the other bulk densities of this study were measured by the cylinder method, $B D_{\text {core }}$. The clod method yields consistently higher values than the cylinder method (Calhoun et al., 2001; VanRemortel and Shields, 1993). To correct for this difference in mineral soils, the same equation used in VanRemortel and Shields (1993) was applied (Eq. 1). A similar correction equation has not been published for organic soils to our knowledge. Yet, organic layer bulk densities measured by the clod method were between 1.4 and 5 times greater than by the core method (using a subset of data including black spruce stands only). Therefore, organic horizon bulk density measurements by the clod method were excluded and treated as if they were missing data. For organic carbon concentration, some NCSS data (26\% of the total dataset) was measured only by the WalkleyBlack method, \% $C_{\text {org }}$ (e.g. method 6A1c; Burt, 2004). The rest of the dataset was measured by dry combustion, $\% C_{\text {tot }}$ (methods $4 \mathrm{H} 2 \mathrm{a}$ or $6 \mathrm{~A} 2 \mathrm{~d}$; Burt, 2004). Therefore, a relation was found so that in cases where only $\% C_{\text {org }}$ data was available, it was adjusted to more closely match $\% C_{\text {tot }}$ (Eq. 2).

In the Arctic Tundra many profiles were highly cryoturbated which requires specialized methods of calculating SOC content (e.g. Michaelson et al., 1996). The 1-m SOC estimates for highly cryoturbated profiles in this study included only those with published values (Bockheim, 2007; Bockheim and Hinkel, 2007; Bockheim et al., 1999; Michaelson et al., 1996; Ping et al., 1997) and therefore no bulk density predictions were necessary. Non-cryoturbated soils whether organic or mineral, or frozen or unfrozen, were predicted by a separate relation specific to arctic soils (Eq. 13; see also Bockheim et al., 2003 for a similar equation).

\section{Appendix Table 1}

Gap-filling equations.

\begin{tabular}{lc}
\hline Equations & adj. $\mathrm{R}^{2}$ \\
\hline Adjustment equations & \\
1. $B D_{a d j}=B D_{\text {core }}=\frac{B D_{\text {clod }}-0.068}{1.011}$ & 0.98 \\
2. $\% C_{\text {adj }}=\% C_{\text {tot }}=0.2107+0.8830 * \% C_{\text {org }}$ & 0.98 \\
Prediction equations for mineral soils & \\
3a. $B D_{\text {min }}=0.4189+e^{-0.1868 * \% C_{\text {tot }}}$ & 0.64 \\
3b. $\% C_{\text {pred }}=-\frac{\log \left(B D_{\text {core }}-0.4223\right)}{0.1890}$ & 0.54 \\
4. $B D_{A}=0.3417+e^{-0.1712 * \% C_{\text {tot }}}$ & 0.59 \\
5. $B D_{B}=0.4671+e^{-0.1915 * \% C_{\text {tot }}}$ & 0.52 \\
6. $B D_{C}=0.6560+e^{-0.2466 * \% C_{\text {tot }}}$ & 0.49 \\
7. $B D_{f r z n}=0.3105+e^{-0.1400 * \% \text { tot }}$ & 0.48 \\
Prediction equations for organic soils & \\
9. $S O C_{O}=0.0085+0.0334 * T h$ & 0.47 \\
10. $S O C_{O i}=0.0109+0.0183 * T h$ & 0.38 \\
11. $S O C_{O e}=0.0269+0.0411 * T h$ & 0.59 \\
12. SOC $C_{O a}=0.0743+0.0354 * T h$ & 0.63 \\
Prediction equation for all arctic soils-frozen or unfrozen, mineral or organic \\
13. $B D=0.0577+e^{-0.0694 * \% C_{\text {tot }}}$ & 0.60
\end{tabular}

\section{References}

Amundson, R., 2001. The carbon budget in soils. Annual Review of Earth and Planetary Sciences 29, 535-562.

Balshi, M.S., McGuire, A.D., Duffy, P., Flannigan, M., Kicklighter, D.W., Melillo, J., 2009. Vulnerability of carbon storage in North American boreal forests to wildfires during the 21st century. Global Change Biology 15 (6), 1491-1510.

Barber, V., Juday, G., Finney, B., 2000. Reduced growth of Alaskan white spruce in the twentieth century from temperature-induced drought stress. Nature 405 (6787), 668-673.

Bliss, N.B., Maursetter, J., 2010. Soil organic carbon stocks in Alaska estimated with spatial and pedon data. Soil Science Society of America Journal 74 (2), 565

Bockheim, J.G., 2007. Importance of cryoturbation in redistributing organic carbon in permafrost-affected soils. Soil Science Society of America Journal 71 (4), 1335.

Bockheim, J.G., Hinkel, K.M., 2007. The importance of "deep" organic carbon in permafrost-affected soils of arctic Alaska. Soil Science Society of America Journal 71 (6), 1889.

Bockheim, J.G., Everett, L., Hinkel, K.M., Nelson, F.E., Brown, J., 1999. Soil organic carbon storage and distribution in arctic tundra, barrow, Alaska. Soil Science Society of America Journal 63, 934-940.

Bockheim, J.G., Hinkel, K.M., Nelson, F.E., 2003. Predicting carbon storage in tundra soils of arctic Alaska. Soil Science Society of America Journal 67, 948-950.

Bonan, G., Shugart, H., 1989. Environmental factors and ecological processes in boreal forests. Annual Review of Ecology and Systematics 20 (1), 1-28.

Bond-Lamberty, B., Thomson, A., 2010. Temperature-associated increases in the global soil respiration record. Nature 464 (7288), 579-582.

Bureau of Land Management, A.F.S, 2008. Alaska historical wildland fire perimeters from 1942 to 2007. In: Michigan, E.R.I.o. (Ed.), Alaska Geospatial Data Clearinghouse (AGDC).

Burt, R., 2004. Soil survey laboratory methods manual. NRCS Soil Survey Investigations Report No. 42.

Calhoun, F., Smeck, N., Slater, B., Bigham, J., Hall, G., 2001. Predicting bulk density of Ohio soils from morphology, genetic principles, and laboratory characterization data. Soil Science Society of America Journal 65 (3), 811.

Callesen, I., Liski, J., Raulund-Rasmussen, K., Olsson, M.T., Tau-Strand, L., Vesterdal, L., Westman, C.J., 2003. Soil carbon stores in Nordic well-drained forest soils - relationships with climate and texture class. Global Change Biology 9, 358-370.

Daly, C., Taylor, G.H., Gibson, W.P., Parzybok, T.W., Johnson, G.L., Pasteris, P., 2001. High quality spatial climate data sets for the United States and beyond. Transactions of ASAE 43, 1957-1962.

Davidson, E.A., Janssens, I.A., 2006. Temperature sensitivity of soil carbon decomposition and feedbacks to climate change. Nature 440 (7081), 165-173.

Davidson, E.A., Belk, E., Boone, R.D., 1998. Soil water content and temperature as independent or confounded factors controlling soil respiration in a temperate mixed hardwood forest. Global Change Biology 4 (2), 217-227.

Dutta, K., Schuur, E.A.G., Neff, J.C., Zimov, S.A., 2006. Potential carbon release from permafrost soils of Northeastern Siberia. Global Change Biology 12 (12), 2336-2351.

Edwards, M., Armbruster, W., 1989. A tundra-steppe transition on Kathul Mountain, Alaska, USA. Arctic and Alpine Research 21 (3), 296-304.

Environmental Systems Research Institute, 2010. ArcMap 9.3. ESRI, Redlands, California.

Fan, Z., Neff, J.C., Harden, J.W., Wickland, K.P., 2008. Boreal soil carbon dynamics under a changing climate: a model inversion approach. Journal of Geophysical Research 113 (G4), G04016.

Guo, Y., Gong, P., Amundson, R., Yu, Q. 2006. Analysis of factors controlling soil carbon in the conterminous United States. Soil Science Society of America Journal 70 (2), 601.

Harden, J., Trumbore, S., Stocks, B., Hirsch, A., Gower, S., O'neill, K., Kasischke, E., 2000. The role of fire in the boreal carbon budget. Global Change Biology 6 (S1), 174-184.

Harden, J., Meier, R., Silapaswan, C., Swanson, D., McGuire, A., 2001. Soil drainage and its potential for influencing wildfires in Alaska. Studies by the US Geological Survey in Alaska, pp. 139-144.

Harden, J.W., Manies, K.L., Turetsky, M.R., Neff, J.C., 2006. Effects of wildfire and permafrost on soil organic matter and soil climate in interior Alaska. Global Change Biology 12 (12), 2391-2403.

Harden, J., Fuller, C., Wilmking, M., Myers-Smith, I., Trumbore, S., Bubier, J., 2008. The fate of terrestrial carbon following permafrost degradation: detecting changes over recent decades . In: Kane, D.L., Hinkel, K.M. (Eds.), Proceedings of Ninth International Conference on Permafrost, 29 June - 3 July, Fairbanks, Alaska, pp. 649-654.

Hinzman, L, Viereck, L., Adams, P., Romanovsky, V., Yoshikawa, K. 2006. Climate and permafrost dynamics of the Alaskan boreal forest. In: Chapin III, F.S. (Ed.), Alaska's Changing Boreal Forest. Oxford University Press, New York, pp. 39-61.

Homer, C., Huang, C., Yang, L., Wylie, B., Coan, M., 2004. Development of a 2001 national landcover database for the United States. Photogrammetric Engineering and Remote Sensing 70, 829-840.

Intergovernmental Panel on Climate Change (IPCC), 2007. Climate change 2007: the physical science basis. Contribution of Working Group 1 to the Fourth Assessment Report of the Intergovernmental Panel on Climate Change, New York.

Jenny, H., 1941. Factors of Soil Formation. New York.

Jorgenson, M.T., Osterkamp, T.E., 2005. Response of boreal ecosystems to varying modes of permafrost degradation. Canadian Journal of Forest Research 35 (9), 2100-2111.

Jorgenson, M., Racine, C., Walters, J., Osterkamp, T., 2001. Permafrost degradation and ecological changes associated with a warming climate in Central Alaska. Climatic Change 48 (4), 551-579.

Jorgenson, M.T., Yoshikawa, K., Kanveskiy, M., Shur, Y.L., Romanenkov, V.A., Marchenko, S., Grosse, G., Brown, J., Jones, B., 2008. Permafrost characteristics of Alaska. Proceedings Ninth International Conference on Permafrost, Fairbanks, AK. University of Alaska, Fairbanks, AK, pp. 121-122. 
Jorgenson, M.T., Romanovsky, V., Harden, J., Shur, Y., O'Donnell, J., Schuur, E.A.G. Kanevskiy, M., Marchenko, S., 2010. Resilience and vulnerability of permafrost to climate change. Canadian Journal of Forest Research 40 (7), 1219-1236.

Kane, E.S., Vogel, J.G., 2009. Patterns of total ecosystem carbon storage with changes in soil temperature in boreal black spruce forests. Ecosystems 12 (2), 322-335.

Kasischke, E.S., Williams, D., Barry, D., 2002. Analysis of the patterns of large fires in the boreal forest region of Alaska. International Journal of Wildland Fire 11, 131-144.

Kauppi, P., Posch, M., 1985. Sensitivity of boreal forests to possible climatic warming. Climatic Change 7 (1), 45-54.

Mack, M., Schuur, E., Bret-Harte, M., Shaver, G., Chapin, F., 2004. Ecosystem carbon storage in arctic tundra reduced by long-term nutrient fertilization. Nature 431 (7007), 440-443.

McCune, B., Dylan, K., 2002. Equations for potential annual direct incident radiation and heat load. Journal of Vegetation Science 13, 603-606.

McGuire, A.D., Anderson, L.G., Christensen, T.R., Dallimore, S., Guo, L., Hayes, D., Heimann, M., Lorenson, T.D., Macdonald, R.W., Roulet, N., 2009. Sensitivity of the carbon cycle in the Arctic to climate change. Ecological Monographs 79 (4), 523-555.

Michaelson, G.J., Ping, C.L., Kimble, J.M., 1996. Carbon storage and distribution in tundra soils of arctic Alaska, U.S.A. Arctic and Alpine Research 28 (4), 414-424.

Nowacki, G., Spencer, P., Fleming, M., Brock, T., Jorgenson, T., 2001. Ecoregions of Alaska: 2001. U.S. Geological Survey Open-File Report 02-297 (map).

O'Donnell, J., Turetsky, M., Harden, J., Manies, K., Pruett, L., Shetler, G., Neff, J., 2009. Interactive effects of fire, soil climate, and moss on $\mathrm{CO}^{2}$ fluxes in black spruce ecosystems of interior Alaska. Ecosystems 12 (1), 57-72.

Oechel, W., Van Cleve, K., 1986. The role of bryophytes in nutrient cycling in the taiga. In: Van Cleve, K., Chapin III, F.S., Flanigan, P.W., Viereck, L.A., Dyrness, C.T. (Eds.), Forest Ecosystems in the Alaskan Taiga: A Synthesis of Structure and Function. Springer-Verlag, New York, pp. 121-137.

O'Neill, K. Kasischke, E., Richter, D., 2002. Environmental controls on soil $\mathrm{CO}^{2}$ flux following fire in black spruce, white spruce, and aspen stands of interior Alaska. Canadian Journal of Forest Research 32 (9), 1525-1541.

Ping, C.L., Michaelson, G.J., Kimble, J.M., 1997. Carbon storage along a latitudinal transect in Alaska. Nutrient Cycling in Agroecosystems 49, 235-242.

Ping, C.L., Michaelson, G.J., Kimble, J.M., Everett, L.R., 2002. Organic carbon stores in Alaska soils. In: Lal, R., Kimble, J.M., Follet, R. (Eds.), Agricultural Practices and Policies of Carbon Sequestration in Soils. Lewis Publishers, Boca Raton, LA, pp. 485-494.

Ping, C.L., Clark, M.H., Swanson, D.K., 2004. Cryosols in Alaska. In: Kimble, J.M. (Ed.), Cryosols: Permafrost-affected Soils. Springer-Verlag, Berlin, pp. 71-94.

Ping, C.L., Michaelson, G.J., Packee, E.C., Stiles, C.A., Swanson, D.K., Yoshikawa, K., 2005. Soil catena sequences and fire ecology in the boreal forest of Alaska. Soil Science Society of America Journal 69 (6), 1761.

Ping, C.F., Boone, R.D., Clark, M.H., Packee, E.C., Swanson, D.K., 2006. State factor control of soil formation in interior Alaska. In: Chapin, F.S., Oswood, M.W., Van Cleve, K., Viereck, L.A., Verbyla, D.L. (Eds.), Alaska's Changing Boreal Forest. Oxford University Press, New York, NY, pp. 21-38.

Ping, C.L., Michaelson, G.J., Jorgenson, M.T., Kimble, J.M., Epstein, H., Romanovsky, V.E., Walker, D.A., 2008a. High stocks of soil organic carbon in the North American Arctic region. Nature Geoscience 1 (9), 615-619.

Ping, C.L., Michaelson, G.J., Kimble, J.M., Romanovsky, V.E., Shur, Y.L., Swanson, D.K., Walker, D.A., 2008b. Cryogenesis and soil formation along a bioclimate gradient in Arctic North America. Journal of Geophysical Research 113 (G3), G03S12.

Ping, C.L., Michaelson, G.J., Kane, E.S., Packee, E.C., Stiles, C.A., Swanson, D.K., Zaman, N.D., 2010. Carbon stores and biogeochemical properties of soils under black spruce forest, Alaska. Soil Science Society of America Journal 74 (3), 969.

Post, W.M., Emmanuel, W.R., Zinke, P.J., Stangenberger, A.G., 1982. Soil carbon pools and world life zones. Nature 298, 156-159.

Rapalee, G., Trumbore, S., Davidson, E., Harden, J., Veldhuis, H., 1998. Soil carbon stocks and their rates of accumulation and loss in a boreal forest landscape. Global Biogeochemical Cycles 12 (4), 687-701.

Sannikov, S., Goldammer, J., 1996. Fire ecology of pine forests of northern Eurasia. In: Goldammer, J.G., Furyaev, V.V. (Eds.), Fire in Ecosystem of Boreal Eurasia. Kluwer Academic Publishers, Boston.

SAS Institute Inc, 1989-2010. JMP, Version 8.0.1. Cary, NC.

Schoeneberger, P.J., Wysocki, D.A., Benham, E.C., Broderson, W.D. (Eds.), 2002. Field Book for Describing and Sampling Soils, Version 2.0. Natural Resources Conservation Service, National Soil Survey Center, Lincoln, NE.

Schuur, E., Bockheim, J., Canadell, J., Euskirchen, E., Field, C., Goryachkin, S., Hagemann, S., Kuhry, P., Lafleur, P., Lee, H., 2008. Vulnerability of permafrost carbon to climate change: implications for the global carbon cycle. BioScience 58 (8), 701-714.
Schuur, E.A.G., Vogel, J.G., Crummer, K.G., Lee, H., Sickman, J.O., Osterkamp, T.E., 2009. The effect of permafrost thaw on old carbon release and net carbon exchange from tundra. Nature 459 (7246), 556-559.

Smith, P., Fang, C., 2010. A warm response by soils. Nature 464, 499-500.

Soil Survey Laboratory Methods Manual, 1996. Soil Survey Investigations Report No. 42, Version 3.0.

Steltzer, H., 2004. Soil carbon sequestration with forest expansion in an arctic foresttundra landscape. Canadian Journal of Forest Research 34 (7), 1538-1542.

Stottlemyer, R., Rhoades, C., Steltzer, H., 2001. Soil temperature, moisture, and carbon and nitrogen mineralization at a taiga-tundra ecotone, Noatak National Preserve, northwestern Alaska. Studies by the US Geological Survey Professional Paper, 1678, pp. 127-137.

Sturm, M., Racine, C., Tape, K., 2001. Increasing shrub abundance in the Arctic. Nature $411,546-547$.

Swanson, D.K., 1996. Susceptibility of permfrost soils to deep thaw after forest fires in Interior Alaska, U.S.A., and some ecologic implications. Arctic and Alpine Research 28 (2), 217-227.

Tape, K., Sturm, M., Racine, C., 2006. The evidence for shrub expansion in Northern Alaska and the Pan-Arctic. Global Change Biology 12 (4), 686-702.

Tarnocai, C., Canadell, J.G., Schuur, E.A.G., Kuhry, P., Mazhitova, G., Zimov, S., 2009. Soil organic carbon pools in the northern circumpolar permafrost region. Global Biogeochemical Cycles 23 (2), GB2023.

Troth, J., Deneke, F., Brown, L., 1976. Upland aspen/birch and black spruce stands and their litter and soil properties in interior Alaska. Forest Science 22 (1), 33-44.

Turetsky, M., Mack, M., Harden, J., Manies, K., 2005. Spatial patterning of soil carbon storage across boreal landscapes. In: Lovett, G.M., Jones, C.G., Turner, M.G., Weathers, K.C. (Eds.), Ecosystem Function in Heterogeneous Landscapes. Springer, New York, pp. 229-255.

United States Department of Agriculture, N.R.C.S, 2006. Land resource regions and major land resource areas of the United States, the Caribbean, and the Pacific Basin. U.S. Department of Agriculture Handbook, 296.

Van Cleve, K., Oliver, L., Schlentner, R., Viereck, L.A., Dyrness, C.T., 1983. Productivity and nutrient cycling in taiga forest ecosystems. Canadian Journal of Forest Research 13 747-766.

Van Cleve, K., Dyrness, C.T., Marion, G.M., Erickson, R., 1993. Control of soil development on the Tanana River floodplain, interior Alaska. Canadian Journal of Forest Research 23, 941-955.

Van Cleve, K., Viereck, L., Dyrness, C.T., 1996. State factor control of soils and forest succession along the Tanana River in interior Alaska, U.S.A. Arctic and Alpine Research 28 (3), 388-400

VanRemortel, R.D., Shields, D.A., 1993. Comparison of clod and core methods for determination of soil bulk density. Communications in Soil Science and Plant Analysis 24 (17-18), 2517-2528.

Viereck, L., Dyrness, C., Van Cleve, K., Foote, M., 1983. Vegetation, soils and forest productivity in selected forest types in interior Alaska. Canadian Journal of Forest Research 13 (5), 703-720.

Weiss, A.D., 2001. Topographic positions and landforms analysis (conference poster) ESRI International User Conference, San Diego, CA July 9-13.

Wendler, G., Shulski, M., 2009. A century of climate change for Fairbanks, Alaska. Arctic 62 (3), 295.

Wilmking, M., Harden, J., Tape, K., 2006. Effect of tree line advance on carbon storage in NW Alaska. Journal of Geophysical Research 111 (G2), G02023.

Wright, D.J., Lundblad, E.R., Larkin, E.M., Rinehart, R.W., 2005. Benthic Terrrain Modeler (ArcMap Toolbar). Oregon State University.

Wynn, J., Bird, M., Vellen, L., Grand-Clement, E., Carter, J., Berry, S., 2006. Continentalscale measurement of the soil organic carbon pool with climatic, edaphic, and biotic controls. Global Biogeochemical Cycles 20 (1).

Yanai, R.D., Battles, J.J., Richardson, A.D., Blodgett, C.A., Wood, D.M., Rastetter, E.B., 2010. Estimating Uncertainty in Ecosystem Budget Calculations, 13, pp. 239-248.

Yarie, J., 1981. Forest fire cycles and life tables: a case study from interior Alaska. Canadian Journal of Forest Research 11 (3), 554-562.

Yi, S., McGuire, A.D., Harden, J., Kasischke, E., Manies, K., Hinzman, L., Liljedahl, A. Randerson, J., Liu, H., Romanovsky, V., Marchenko, S., Kim, Y., 2009. Interactions between soil thermal and hydrological dynamics in the response of Alaska ecosystems to fire disturbance. Journal of Geophysical Research 114 (G2), G02015.

Zimov, S.A., Davydov, S.P., Zimova, G.M., Davydova, A.I., Schuur, E.A.G., Dutta, K., Chapin, F. S., 2006. Permafrost carbon: stock and decomposability of a globally significant carbon pool. Geophysical Research Letters 33 (20), L20502. 